FIFTY YEARS OF PROGRESS AND

THE NEW RISCAL POLICY 


\section{‘}

. 


$$
-
$$




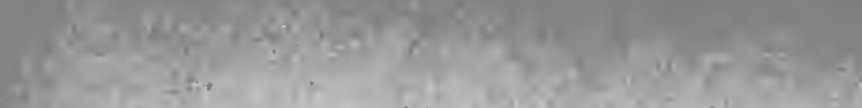

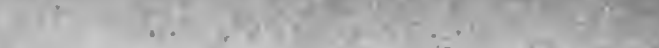

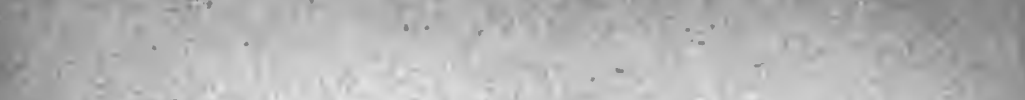

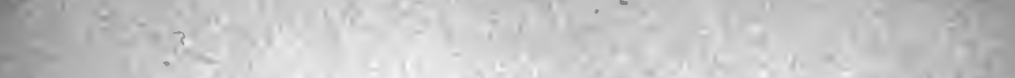

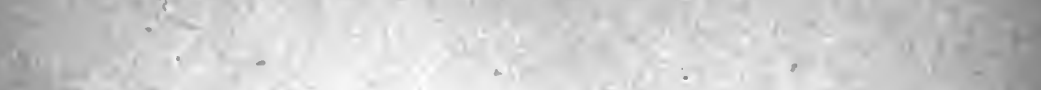

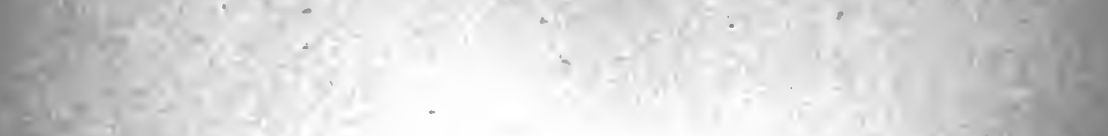

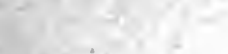

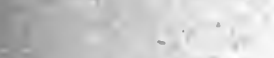

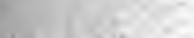

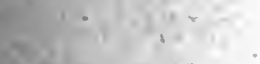

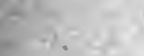

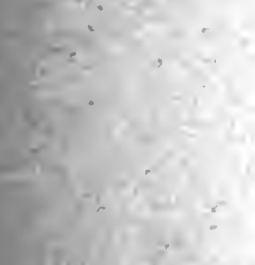

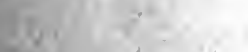

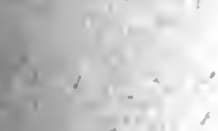

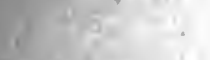

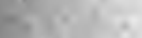

$+1$

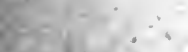

$x=1 \%$

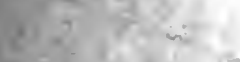

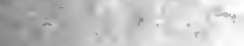

$x^{2}+2+\infty$

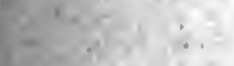

H* +2

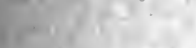

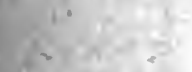

tat

*.2.

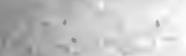

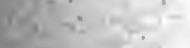

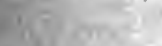

$-5=0,1$

$+4, \ldots+1$

$(1) \cdot 2=$

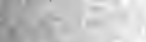

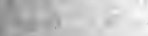

$x+1$

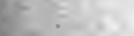

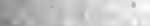

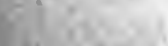




\section{$\mathrm{C}_{3}^{6}$ \\ FIFTY YEARS OF PROGRESS;}

AND

\section{THE NEW FISCAL POLICY.}

BY

LORD BRASSEY, K.C.B., D.C.L.

COMMANDER OF THE LEGION OF HONOUR; AUTHOR OF 'WORK AND WAGES' ETC.

' Fifty years of ever-broadening Commerce! Fifty years of ever-brightening Science! Fifty years of ever-widening Empire!'

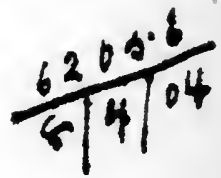

LONGMANS, GREEN, A N C C.

39 PATERNOSTER ROW, LONDON,

NEW YORK AND BOMBAY.

1904. 
The following pages are a compilation from Blue-books, leaflets, and speeches-some delivered by the present woriter, the greater number, and, needless to say, the more valuable, by leading statesmen.-B. 


\section{CONTENTS}

CHAPTER PAGE

I statistics of trade and progress of the Nation . . 5

II Staple industries AND Miscellaneous trades $\quad . \quad . \quad 17$

III THE NEW fiscal policy: THE PROPOSALS AND THEIR FINANCIAL EFFECT . . . . . . . . 26

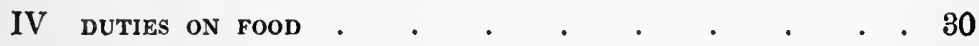

$V$ FISCAL UNION OF THE EMPIRE . . . . . . . 35

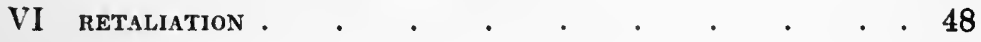

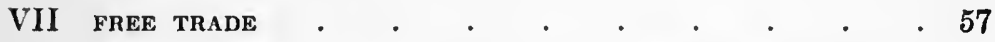

VIII SOCIAL AND ECONOMIC CONDITIONS AT HOME AND ABROAD: . UNDER PROTECTION-UNDER FREE TRADE . • . . 64

IX imperial CO-OPERAtion in Colonial Development . . 74

X Neglected opportunities For Trade: NeW EMPLOYMENTS FOR THE LEAST CAPABLE . . . . . . . . 78

XI REDUCTION OF WAR EXPENDITURE . . . . . 84

XII TRADE WITH TROPICAL COUNTRIES . . . . . . . 87

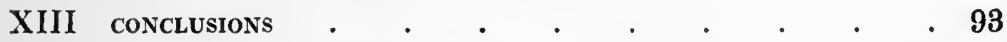

XIV INQUIRY BY ROYAL COMMISSION . . . . . . 102 APPENDIX . . . . . . . . . . . . . 105 
Digitized by the Internet Archive in 2007 with funding from

Microsoft Corporation 


\title{
FIFTY YEARS OF PROGRESS;
}

\author{
AND \\ THE NEW FISCAL POLICY
}

\section{CHAPTER I}

STATISTICS OF TRADE AND PROGRESS OF THE NATION

The progress of trade must be traced in statistics. Statistical The following tables are compiled from official returns :

Exports of British and Irish Produce, excluding Ships

$$
\begin{array}{llllll}
1863-72 & \ldots & \ldots & \ldots & \ldots & £ 189,130,000 \\
1873-82 & \ldots & \ldots & \ldots & \ldots & £ 220,065,000 \\
1883-92 & \ldots & \ldots & \ldots & \ldots & £ 234,116,000 \\
1893-1902 & \ldots & \ldots & \ldots & \ldots & £ 245,442,000 \\
1903 & \ldots & \ldots & \ldots & \ldots & £ 287,000,000
\end{array}
$$

Exports of Donestic Produce compared

Five years' average :

$\begin{array}{lccccc}\text { United Kingdom } & \ldots & \ldots & 234 & 249 \\ \text { France } & \ldots & \ldots & \ldots & 138 & 150 \\ \text { Germany } & \ldots & \ldots & \ldots & 156 & 192 \\ \text { United States } & \ldots & \ldots & 186 & \text { - }\end{array}$




\section{III}

Exports per Head of Population for the Quinquennial Periods BEGINNING 1870-74

Exports.

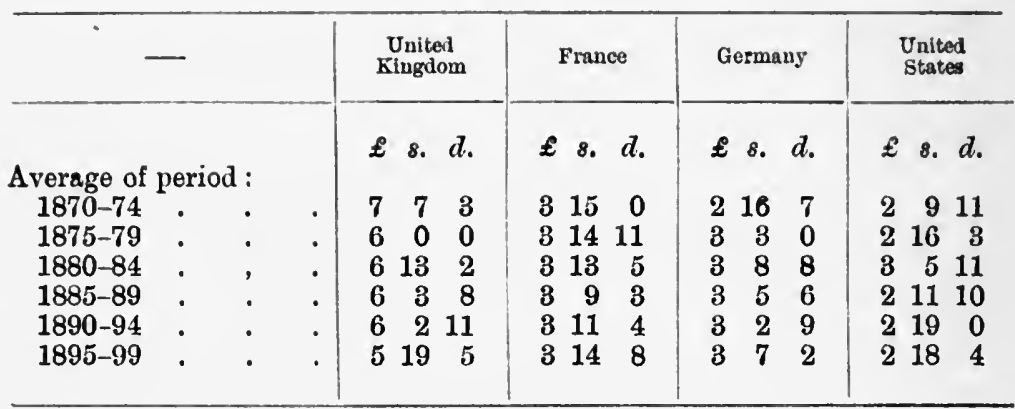

IV

Net Imports per Head of the Population for the Quinquennial Periods beginning 1870-74

Imports.

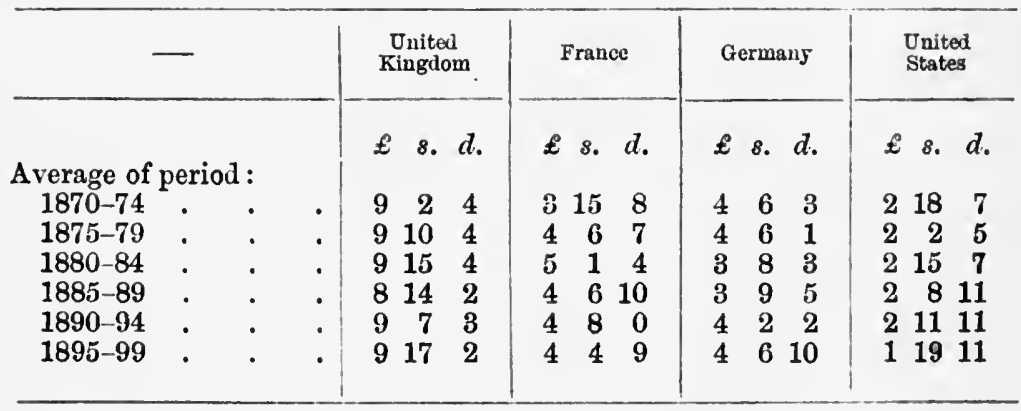

V

United Kingdom-including value of Ships-1900-3

Imports (net) $\mathfrak{1 1}$. 1s. 5d., Exports $26.17 s .1 d$. per head.

Gernany- Commerce Spécial' (including Improvement Trade)1900-2

Imports 24 . 19s. 5d., Exports 24. 1s. 1d. per head. 
The population of the United Kingdom for this comparison is taken at average of $1900-3$, whereas the population of Germany is taken as in 1900, thus exaggerating German trade per head.

The fiscal controversy turns specially on exports of manufactures. Our relative progress for the last five years is as follows:-United Kingdom, 1897, $2198,000,000$; 1902, £227,600,000; Germany, 1896, £115,000,000 ; 1901, £144,600,000. In both countries the same increase- $£ 29,600,000$, but, as we have reason to believe, with a difference in the financial results. The trade of the United Kingdom was on a sound commercial basis. Germany-ahead perhaps in technical education, not our superior in the commercial faculty-has lately gone through a severe crisis, now, happily, passing away. With the aid of borrowed money, production had been unduly expanded. The home market had been glutted, and stocks had been dumped down in foreign markets. The heavy loss on sales abroad was in some degree covered by higher prices in the home market, under the protection of tariffs.

Four times, at intervals of five years, the trade position of the United Kingdom has been reviewed by Board of Trade skilled and impartial observers at the Board of Trade. In his report, made in 1888, Sir Robert Giffen gave special attention to the relative progress of the United Kingdom and Germany. In Europe, Germany was running us hard in northern, France in southern countries; yet, in general, the proportion was higher for Great Britain than for France or Germany. Outside Europe the preponderance of the United Kingdom was beyond question, and in British possessions over- 
whelming. A similar review of the position in 1894 and 1897 gave the same results.

The report by the Board of Trade in 1902 is not less reassuring than those of former years. 'In spite of the strides made by Germany and the United States in recent years, we in the United Kingdom still preponderate greatly as a country manufacturing for export. Measured per head of the population, we are far ahead of Germany or any of our competitors. The imports per head are more than double those of any other countries; nearly five times the imports per head of the United States. And none of the countries named are gaining. Germany comes nearest to the United Kingdom. We are still far ahead both in the aggregate value of our trade and in the proportion of manufactured goods to our total exports.'

Germany. The increasing pressure of German competition has been with many the cause of keener anxiety than the facts would seem to justify. Comparing 1880-84. with 1896-1900, our imports from Germany increased 4.8 per cent.; our exports to Germany 30 per cent. Imports from Germany increased, though not considerably, in cotton, woollen, glass, and iron manufactures. In each of these articles our exports to all countries were far in excess of our imports from Germany. In 1896-1900 our annual imports of cotton manufactures from Germany averaged $£ 698,000$; our total exports were over $£ 58,000,000$. Imports of woollens from Germany $£ 1,048,000$; exports to all countries, $£ 15,700,000$. Imports of iron and steel manufactures from Germany, £890,000 ; exports to all countries, $£ 49,000,000$. As the result of a survey 
extending over the five years 1896-1900, the Board of 'Trade had found 'in our home markets no material displacement of our home manufactures by Germany.'

With the United States we in the United Kingdom could not compete in magnitude of trade under any United fiscal system. 'The progress of the United States is due to natural advantages which we do not possess, and to the demands of a home market such as the United Kingdom cannot offer. A free-trade America would be a formidable competitor in neutral markets.

When we turn to the tables in the Blue-book, giving the distribution of our exports as between foreign countries and British possessions, we find no appreciable change in a period of twenty years.

VI

Exports of British and Irish Produce

\begin{tabular}{|c|c|c|c|c|c|c|}
\hline \multirow{2}{*}{\multicolumn{2}{|c|}{ Annual average }} & & \multicolumn{2}{|c|}{ Foreign Oountries } & \multicolumn{2}{|c|}{ British Possessions } \\
\hline & & & Amount & Per cent. & Amount & Per cent. \\
\hline $\begin{array}{l}1880-84 \\
1895-99\end{array}$ & . $\quad$. & . & $\begin{array}{c}\text { Million } £ \\
153 \\
157\end{array}$ & $\begin{array}{l}65 \cdot 5 \\
66 \cdot 0\end{array}$ & $\begin{array}{c}\text { Million }{ }^{2} \\
81 \\
81\end{array}$ & $\begin{array}{l}34 \cdot 5 \\
34 \cdot 0\end{array}$ \\
\hline
\end{tabular}

Colonial and foreign trade.

Our imports vastly exceed our exports. To quote from Mr. Chiozza-Money: 'We are enriched by our imports, imports. Our exports impoverish us, unless in return we receive as good or better value in imports.' Adding to the value of our exports the returns from shipping $(£ 90,000,000)$, from foreign investments $(£ 52,500,000)$, and over $£ 27,000,000$ for private trade investments, the balance of trade has been fully maintained. 


\section{VII}

Value of the Total Imports and Exponts of Merchandise from and to Foreign Countries and Britisu Possessions (including Protectorates) respectively, exclusive of Foreign Merchandise transhipped under Bond at Ports in the United Kingdom, aNd OF Bullion and SPecie

Total

imports

and

exports.

Home trade.

Home invest. ments.

\begin{tabular}{|c|c|c|c|c|c|}
\hline $\begin{array}{l}\text { 1mports and Exports } \\
\text { (Total) }\end{array}$ & 1898 & 1899 & 1900 & 1901 & 1902 \\
\hline $\begin{array}{l}\text { From and to Foreign } \\
\text { Countries } \\
\text { From and to British } \\
\text { Possessions (in- } \\
\text { cluding Protecto- } \\
\text { rates). }\end{array}$ & $\begin{array}{c}\mathcal{E} \\
574,824,937 \\
\\
189,733,753\end{array}$ & $\begin{array}{c}£ \\
618,491,350 \\
201,078,891\end{array}$ & $\begin{array}{c}£ \\
665,894,228 \\
211,554,689\end{array}$ & $\begin{array}{c}£ \\
651,162,896 \\
\\
218,692,070\end{array}$ & $\begin{array}{c}\mathcal{E} \\
653,325,538\end{array}$ \\
\hline Total & $764,558,690$ & $814,570,241$ & $877,448,917$ & $869,854,466$ & $877,630,053$ \\
\hline
\end{tabular}

Internal trade is even more important than external. The wages of those employed in producing goods for our foreign customers do not exceed $£ 130,000,000$; the total wages bill of the United Kingdom has been computed at no less than from $£ 700,000,000$ to $£ 750,000,000$. The value of the goods produced for the home market is proportionate to the wages paid.

The progress of our home trade is indicated roughly by the goods traffic on our railways. In 1890-94 $308,000,000$ tons of goods were carried on the railways of the United Kingdom, or 8.08 tons per head of the population. In $1895-99,371,000,000$ tons were carried, or 9.37 tons per head. In 1902 the tons carried were no less than $437,000,000$, or 10.43 tons per head.

The internal trade and economic progress of the United Kingdom were discussed in The Statist in its issue of July 11. In the ten years 1881-90 we had lent to Colonies and to foreign countries a vast sum, 
estimated at no less than $£ 559,000,000$. Crises and breakdowns of credit put a check on investments in foreign countries. The accumulation of capital continued. It found investment at home. The tables published by the Commissioners of Inland Revenue show on how prodigious a scale :

Gross Amount of Income brought under the Review of the Inland Revenue Department for the purposes of Income Tax from our Investments in Home Securities and Houses

\begin{tabular}{|c|c|c|c|c|}
\hline- & & $1880-81$ & $1890-91$ & $1900-01$ \\
\hline British. & & $£$ & $£$ & $£$ \\
\hline \multirow{9}{*}{$\begin{array}{l}\text { Government securities } \\
\text { Railways : } \\
\text { Mines and quarries : } \\
\text { Gasworks : } \\
\text { Waterworks : } \\
\text { Canals : } \\
\text { Other public companies } \\
\text { Municipal loans, \&c. } \\
\text { Houses }\end{array}$} & & $20,001,000$ & $15,579,000$ & $14,112,000$ \\
\hline & & $29,131,000$ & $36,445,000$ & $40,674,000$ \\
\hline & & $7,592,000$ & $9,741,000$ & $13,693,000$ \\
\hline & & $4,505,000$ & $5,120,000$ & $6,362,000$ \\
\hline & & $2,653,000$ & $3,568,000$ & $4,676,000$ \\
\hline & & $3,196,000$ & $3,490,000$ & $3,426,000$ \\
\hline & & $26,429,000$ & $63,544,000$ & $155,383,000$ \\
\hline & & $4,992,000$ & $7,167,000$ & $9,240,000$ \\
\hline & & $117,466,000$ & $140,584,000$ & $178,963,000$ \\
\hline & & $215,965,000$ & $285,238,000$ & $426,529,000$ \\
\hline
\end{tabular}

All the indications point to an improving condition of the people. The population since 1872 has increased by $10,000,000$ persons. This increase would have Improved condition of the people. been impossible unless our trade had improved. The gross annual value of the property and profits assessed to income tax is growing by strides rather than by steps. The amount for the five years 1890-94 averaged $£ 703,000,000$. In 1902 the amount had increased to no less than $£ 902,000,000$. For the masses of our population, no test of progress can be more conclusive than the deposits in the Post-Office and trustee savings' banks. The average amount rose from 
$£ 163,000,000$ in $1895-99$, and $£ 187,000,000$ in 1900 , to $£ 197,000,000$ in 1902 . 'The number of depositors increased from $8,787,000$ in $1895-99$ to $10,803,000$ in 1902. 'The Board of Trade gives yet another statistic by which our financial progress may be measured. 'The registered companies carrying on business in the United Kingdom in April, 1892, numbered 16,173 ;

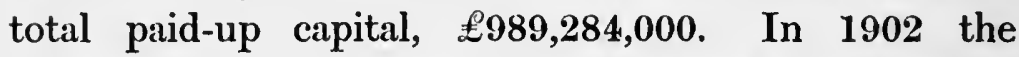
companies had increased to 33,629 , and their capital to $£ 1,805,141,000$.

National income.

The national income for the United Kingdom, France, and Germany was compared by Mr. Asquith in a recent speech. 'France has a national income of about $£ 1,000,000,000$ for a population of $38,000,000$; Germany, with its huge population of $55,000,000$, has a national income of $£ 1,300,000,000$; the United Kingdom has, for a population of only $41,500,000$, against Germany's 55,000,000, a national income of no less than $£ 1,650,000,000$, against the $£ 1,300,000,000$ of Germany with its larger population.'

\section{VIII}

From Statistical Abstract for the United States, 1902

\begin{tabular}{|c|c|c|c|}
\hline- & France & Germany & United Kingdom \\
\hline $\begin{array}{l}\text { Imports. } \\
\text { Exports. } \\
\text { Indebtedness }\end{array}$ & $\begin{array}{c}£ \\
168,650,880 \\
154,899,400 \\
1,160,138,362\end{array}$ & $\begin{array}{c}\stackrel{\mathcal{E}}{\mathbf{E}} \\
258,050,820 \\
210,937,000 \\
634,506,524\end{array}$ & $\begin{array}{c}\stackrel{f}{£} \\
508,041,060 \\
272,545,778 \\
612,185,260\end{array}$ \\
\hline Population & $38,514,000$ & $55,976,000$ & $40,906,000$ \\
\hline $\begin{array}{l}\text { Per capita of imports } \\
\text { Exports. } \\
\text { Debt } \\
\text { Interest (rate per cent.) }\end{array}$ & \begin{tabular}{r}
\multicolumn{1}{c}{8} \\
$23 \cdot 63$ \\
$20 \cdot 88$ \\
$150 \cdot 61$ \\
$6 \cdot 28$
\end{tabular} & 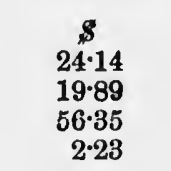 & $\begin{array}{c}\$ \\
62 \cdot 10 \\
33 \cdot 81 \\
74 \cdot 83 \\
2 \cdot 76\end{array}$ \\
\hline
\end{tabular}


The opinion of the Commission on the Depression Commisof Trade, as given in their final report, is as true to-day as in 1886. Having referred to the statistics showing sion on depression of trade. that, exclusive of those engaged in agriculture, profits and the numbers assessed to income tax were increasing, they observe: "There is distinct evidence that profits are becoming more widely distributed among the classes engaged in trade and industry. While the larger capitalists may be receiving a lower return than that to which they have been accustomed, the number of those who are making a profit, though possibly a small one, has largely increased. . . .

'There is no feature of the situation which we have been called upon to examine so satisfactory as the immense improvement which has taken place in the condition of the working classes during the last twenty years. The workman in this country is, when fully employed, in almost every respect in a better position than his competitor in foreign countries, and we think that no diminution in our productive capacity has resulted from this improvement in his position.'

An equally reassuring view was expressed by the Labour Labour Commission in their final report issued in 1894: $:$ sion. - The impression left by the evidence as a whole is that among the more settled and stable population of skilled workpeople there has during the last half-century been considerable and continuous progress in the general improvement of conditions of life, side by side with the establishment of strong trade custom adapted to the modern system and scale of industry. Experience may fairly be said to have shown that this part of the population possesses in a highly remarkable degree the power 
of organisation, self-government, and self-help. Workpeople of this class earn better wages, work fewer hours, have secured improved conditions of industrial and domestic life in other respects, and have furnished themselves through trade unions and friendly societies with means of providing against the various contingencies of sickness, accidents, and temporary want of employment.

'The classes who compose the lower grades of industry, regarded as a whole, have probably benefited no less than the skilled workers from the increased efficiency of production, from the advantages conferred by legislation, from the cheapening of food and clothing, and from the opening out of new fields for capital and labour. In their case also the improvement manifests itself in better pay and more favourable conditions of work; but chiefly in this, that of the mass of wholly unskilled labour, part has been absorbed into higher grades, while the percentage of the total working population earning bare subsistence wages has been greatly reduced.

' 'There is still a deplorably large residuum of the population, chiefly to be found in our large cities, who lead wretchedly poor lives, and are seldom far removed from the level of starvation; but it would seem that not only the relative, but perhaps even the actual numbers of this class are also diminishing.'

By industry, by maritime enterprise, by our command of supplies of iron and coal at a time when the mineral resources of other States were undeveloped, by an early advance in mechanical science, we have been enabled to maintain our crowded population of nearly 
$42,000,000$ in conditions constantly improving for the greater number. Mr. Balfour, towards the conclusion $\mathrm{Mr}$. of his pamphlet, gives his opinion in these words: $\begin{gathered}\text { Balfour's } \\ \text { pamphlet. }\end{gathered}$ 'Judged by all available tests, both the total wealth and the diffused well-being of the country are greater than they have ever been. We are not only rich and prosperous in appearance, but also, I believe, in reality. I can find no evidence that we are living on our capital.' May we not therefore concur with Lord Rosebery, Lord when he said: 'The burden of proof lies with those who Rosebery. attack our fiscal system. Had free trade failed us in the fifty-seven years of experience we have had of it, had we found ourselves with a shrinking trade, a diminished revenue, a population on the verge of poverty, we should long ago have reversed the whole system of free trade and reconsidered it. But we find ourselves, so far as all statistics can give us a clue, at a pinnacle of wealth such as no nation of the size has ever reached in the history of the world.'

At the Colonial Conference, on the occasion of the Diamond Jubilee of her late lamented Majesty, Mr. Mr. Cham berlain. Chamberlain spoke as follows: 'Sir Robert Giffen's conclusions were much more favourable to this country than the general impression which seemed to exist. His investigations showed that, in regard at all events to the value of the trade, we were losing much less than was supposed, and what we lost in one direction was made up in another. 'To a certain extent that was confirmed by the general condition of things in this country. Take the present time: although there were always trades which were not doing well, there was no doubt that for the last few years the prosperity of this 
country had been remarkable and almost universal, and yet it was the case that certain trades had left us altogether. In his opinion, that was largely because the manufacturers engaged in them had found more profitable work to do ; it was partly because they had not taken the trouble which they ought to have taken, and they might have cause to regret this whenever trade was bad in this country again. The matter was one of very great interest; but, having had considerable experience, having been himself at the Board of Trade for five years, he had not much confidence in good resulting from inquiry.'

With a population not comparable in numbers with the great nations of Continental Europe, confined within the narrow area of small islands, not surpassingly rich in natural resources, we have made our country in a large degree the workshop of the world, and its financial centre. Our success is due not only to the ability with which commerce and enterprise in all departments are conducted, but also to freedom from the restrictions of protective tariffs. 


\section{CHAP'TER II}

STAPIE INDUSTRIES AND MISCELIANEOUS TRADES

Having traced the general progress of trade, let us examine in detail the condition of those industries described by the advocates of a change in our fiscal policy as in a decaying condition.

\section{Iron Trade}

It has been alleged that 'the iron trade is going.' Iron The statistics do not justify a desponding view.

Exports of Iron and Steel and Manufactures thereof

(Twelve Monthis)

\begin{tabular}{|c|c|c|}
\hline 1901 & 1932 & 1903 \\
\hline$\stackrel{f}{\stackrel{E}{25,008,757}}$ & $\underset{28,877,337}{£}$ & $\stackrel{f}{\stackrel{f}{30,453,190}}$ \\
\hline
\end{tabular}

Profits of the trade, returned for income tax, 1898$£ 2,556,392 ; 1902$, $66,600,263$. Persons employed$1861,129,507 ; 1891,202,406 ; 1901,216,022$.

Exports of Steam-engines and Machinery

(Twelve MoNThs)

\begin{tabular}{|c|c|c|}
\hline 1901 & 1902 & 1903 \\
\hline$\stackrel{f}{\stackrel{f}{17,812,344}}$ & 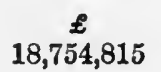 & $\stackrel{£}{\stackrel{\ell}{20,065,916}}$ \\
\hline
\end{tabular}


Steam. engines and machinery.

Cutlery and hard ware.

Tin plates.

\begin{tabular}{|c|c|c|}
\hline 1901 & 1902 & 1903 \\
\hline$\underset{4,175,441}{\ell}$ & $\stackrel{\stackrel{f}{f}}{4,384,672}$ & $\stackrel{£}{£}$ \\
\hline
\end{tabular}

Average-1878-1882, £9,186,627; 1898-1902, $£ 18,846,000$. Persons employed-1881, 217,000 ; $1891,292,000 ; 1901$, further increase not yet officially stated.

Exports of Cutlery, Hardware, Implements, and Instruments

\section{Miscellaneous 'Trades}

\section{Tin Plates}

$\begin{array}{crllll}\text { Exports } & 1881-1890 & \ldots & \ldots & 65,869,180 & \text { cwts. } \\ , & 1891-1900 & \ldots & \ldots & 65,228,880 \quad,\end{array}$

In 1902 the tin-plate industry had one of the best years since the McKinley tariff was adopted. In the three years 1900-2, the exports to the United States fell to an average of 66,300 tons, as compared with 318,000 tons in 1890 . The loss was balanced by the increase of trade elsewhere from 103,600 tons in 1890 to an average of 219,000 tons in 1900-2. In 1902 our total exports, including those to the United States, were 311,869 tons-the largest since 1895. Our cxports to other countries, excluding the United States, were 246,727 tons-the largest on record. The Labour Department reported 19,800 persons employed at 397 mills in 1902, compared with 16,960 persons at 319 mills in 1896. 


\section{Galvanised Sheets.}

Dumped raw materials have caused a large increase Galran. in the manufacture of galvanised sheets. Exports in ised $1900,247,177$ tons ; in $1903,352,496$ tons.

\section{Brass}

Exports-1898, £471,234；1903, £719,910.

Bras3.

Wire Trade

Exports-1898, £772,604; 1903, £1,171,473.

Wire

trade.

Watches

\begin{tabular}{ccccccc} 
& & & & \multicolumn{2}{c}{$\begin{array}{c}\text { No. of Watches } \\
\text { Imported } \\
\text { (Nine Months) }\end{array}$} \\
1901 & $\ldots$ & $\ldots$ & $\ldots$ & $\ldots$ & $\ldots$ & $2,481,329$ \\
1902 & $\ldots$ & $\ldots$ & $\ldots$ & $\ldots$ & $\ldots$ & $2,103,115$ \\
1903 & $\ldots$ & $\ldots$ & $\ldots$ & $\ldots$ & $\ldots$ & $1,620,609$
\end{tabular}

Watches.

\section{Textiles}

Total Consumption of Raw Cotton in the United Kingdom

\begin{tabular}{c|c|c}
\hline Annual Average & Million cwts. & Lb. per head of population \\
\hline $1880-84$ & $12 \cdot 9$ & $41 \cdot 0$ \\
$1890-94$ & $14 \cdot 2$ & $41 \cdot 7$ \\
1900 & $14 \cdot 5$ & - \\
1901 & $14 \cdot 7$ & - \\
1902 & $14 \cdot 6$ & \\
\hline
\end{tabular}

'The volume of our exports of textiles has been steadily maintained to every part of the world except to the United States. Total million yards exported $-1892,4,873 \cdot 1 ; 1902,5,330 \cdot 7$. The increase in exports to India, 'Turkey, Egypt, China, and Java, has made good the loss in the trade with the United States. 
Woo.. Consumption of raw wool . 1890-94, 475,000,000 Ib. .1898-1902, 525,600,000 ,,

'Wool,' it is said, 'is threatened.' 'The McKinley tariff dealt a heavy blow. The trade has been slowly recovering, even with the United States, and with other foreign countries steadily growing. Our woollen manufacturers find their chief market at home, their position in this regard differing essentially from that of manufaeturers of cotton goods.

\section{Chemicals, Drugs, Dyes, and Colours}

\section{Exponts.}

\begin{tabular}{|c|c|c|}
\hline 1901 & 1902 & 1903 \\
\hline$\stackrel{£}{£} 10,963,497$ & 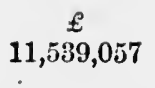 & $\stackrel{\mathfrak{E}}{12,079,554}$ \\
\hline
\end{tabular}

Chemical trade.

The chemical trade has been examined, with the knowledge of an expert, by Mr. Haldane. By the ammoniate-of-soda process the cost of making alkalis is reduced by 50 per cent. Manufacturers of chemicals by antiquated methods have been unable to compete. Our up-to-date manufacturers are prosperous.

\section{Hosiery}

\begin{tabular}{|c|c|c|c|}
\hline Hosiery. & - & Exports & Imports \\
\hline & $\begin{array}{l}1898 \\
1899 \\
1900 \\
1901 \\
1902 \\
1903\end{array}$ & 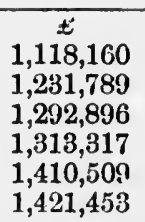 & $\begin{array}{c}£ \\
410,263 \\
371,428 \\
619,752 \\
707,673 \\
832,702 \\
783,263\end{array}$ \\
\hline
\end{tabular}


We have something to learn both in organisation and practical science from our German competitors. 'They are ahead in certain dyes. In no trade in this country has the condition of the worker been more improved. In the 'forties' of the last century the average annual earnings of families wcre $£ 4510 s$. Earnings have been raised to 35s. a week by the use of machines, and by greater skill of hand.

\section{Linoleum}

\begin{tabular}{|c|c|c|c|}
\hline- & 1898 & 1200 & 1902 \\
\hline $\begin{array}{l}\text { Linseed-oil exports } \\
\text { Cotton-seed oil } \\
\text { Other seed oil }\end{array}$ & $\begin{array}{c}\mathcal{E} \\
377,307 \\
323,191 \\
67,645\end{array}$ & $\begin{array}{c}£ \\
\qquad 88,866 \\
428,404 \\
98,014\end{array}$ & $\begin{array}{c}\stackrel{f}{\complement} \\
655,082 \\
660,695 \\
114,116\end{array}$ \\
\hline & 768,143 & $1,115,284$ & $1,429,893$ \\
\hline $\begin{array}{l}\text { Oil-cloth exports : } \\
\text { Oil-cloth imports }\end{array}$ & $\begin{array}{c}1,000,447 \\
\text { Not classified }\end{array}$ & $\begin{array}{r}1,312,893 \\
119,661\end{array}$ & $\begin{array}{r}1,455,849 \\
70,946\end{array}$ \\
\hline
\end{tabular}

The Germain exports of linoleum are less than $£ 50,000$ annually. Profits : British Linoleum Manufacturing Company-1901, £40,870; 1902, £37,000 ; 1903, 249,512. Greenwich Linoleum Company-1901, $£ 26,300 ; 1902, £ 30,200 ; 1903, £ 36,685$.

\section{Glass and Earthentare}

Belgian glass-makers have a local advantage in the Glass and supply of a special glass-sand near at hand. In the ware. quality of their productions British manufacturers are 
nowhere surpassed. Less skilful as traders, they have permitted an undue depression of prices through excessive competition. 'There are no indications of declining trade in the Board of 'Trade returns.

Exponts.

\begin{tabular}{|c|c|c|}
\hline 1901 & 1902 & 1903 \\
\hline $\begin{array}{c}\stackrel{ \pm}{ \pm} \\
3,049,962\end{array}$ & $\underset{2,997,523}{£}$ & $\underset{3,278,797}{£}$ \\
\hline
\end{tabular}

In 1851, 46,524 persons were employed in England and Wales. In 1901 the number rose to 92,556, a growth of 99 per cent. In the same interval the population grew from $17,900,000$ to $32,600,000$, or 82 per cent.

\section{Paper}

Foreign manufacturers of paper have an advantage over British makers in the supply of raw material from the forests of Germany, Scandinavia, and Austria. British exports are inereasing.

ExPoRTs.

\begin{tabular}{|c|c|c|c|}
\hline- & 1901 & 1902 & 1903 \\
\hline $\begin{array}{l}\text { Paper } \\
\text { Stationery, other } \\
\text { than paper }\end{array}$ & $\begin{array}{c}\mathfrak{f} \\
1,668,577 \\
1,227,019\end{array}$ & $\begin{array}{c}\stackrel{ \pm}{ \pm} \\
1,672,704 \\
1,286,457\end{array}$ & 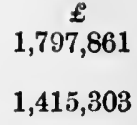 \\
\hline
\end{tabular}

Our mills pay dividends of from 5 to 12 per cent. In Germany and France the dividends average half the amount of those paid in this country. 


\section{Boots}

Exports (dozen pairs) - 1901, 672,543 ; 1903, Boots. 773,701. At no period were more boots and shoes made than at the present day. The introduction of machinery has for a time increased production beyond the demand. There must be ebb and flow in every trade. Our exports to the Colonies have been diminished by the Commonwealth tariff.

\section{Pearl Buttons}

The steam laundry has done more than tariffs to Pearl check the demand for these fragile articles. Superior buttons. qualities have taken their place.

\section{Cheap Jewellery}

\begin{tabular}{cccc}
\multicolumn{5}{c}{ Exports to Foreign Countries } \\
1900 & 1901 & 1902 & Increase \\
$£ 50,545$ & $£ 62,005$ & $£ 62,382$ & $£ 11,837$ \\
& & & \\
1900 & Exports & To Britisi & Possessions \\
$£ 127,659$ & 1901 & 1902 & Decrease \\
& $£ 123,026$ & $£ 120,438$ & $£ 7,221$
\end{tabular}

There is no cause for despair as to the future. Quarterly In discussing the fiscal controversy our trade position Review. has on more than one occasion been examined by the Quarterly Reviewer. In a former number it was said, and said truly: 'The 70,000,000 of Americans and over 100,000,000 of Europeans-Germans, French, Belgians, and Dutch-not only supplying their own 
wants over a large field of industry, which was formerly exclusively our own, but invading Colonial and other markets, and with foreigners becoming lenders to this country instead of borrowers, it is little wonder that the rate of progress in the exports of British manufactures to America and the Continental industrial nations should show a diminishing rate of progress. 'The wonder is that it should show progress at all.'

More recently-in October 1903-the state and progress of trade are once more passed under review by the same competent authority: "Our review of the statistical position has shown that prices thirty years ago were just one-half higher, on the whole, than they are now ; and, if our present trade were measured by the values of thirty years ago, it would be seen that it had increased in volume by more than 50 per cent., and is giving employment to a correspondingly increased number of workpeople. Mr. Chamberlain says the silk trade has gone ; but the average export of "broad stuffs" of silk or satin and silk and other materials for the last five years has been $9,500,000$ yards against 7,500,000 ten years ago, 6,000,000 twenty years ago, and 4,000,000 thirty years ago. Instead of the silk trade having gone, it has more than doubled in thirty years. 'The woollen and iron and steel trades, we are told, are threatened; and cotton will go next. All trades are always being threatened; but threatened men live long, and so do threatened trades. Our average consumption of wool during the last five years has been $526,000,000$ lbs. against $344,000,000$ lbs. twenty years ago, and $320,000,000$ lbs. thirty years ago. Our average consumption of cotton for the last five years has been 
$15,000,000$ lbs., against $11,800,000$ lbs. twenty years ago, and 9,640,000 thirty years ago. Our output of pigiron, too, and the consumption of pig-iron in the United Kingdom during the last five years, in spite of dumping from Germany and America, have been larger than in any similar period.'

Whether under free trade or protection, industries must hare grown in foreign countries. Great Britain could not have supplied the world's demand for manufactures. If our competitors may sometimes show a larger increase, we, too, have been working at high pressure. Our mills have been on full time. Our makers of machinery have refused orders. If in any department we have lost ground, it has been in the cheaper descriptions. In the finer qualities, in the production of which skilled labour commands the most liberal reward, we fully hold our own. 


\section{CHAP'IER III}

THE: NEW HISCAL POLICY : 'THF PROPOSAIS AND THEIR FINANCIAL, EFFEC'T Mr. Is his address at Glasgow, on October 6, Mr. lain's Chamberlain gave the outlines of his plan, and his reasons for advocating changes which must materially affect our commerce. His proposals were :

'To impose--

2s. a quarter on foreign corn, except maize.

A corresponding tax on flour such as 'to give a substantial preference to the miller.'

5 per cent. on foreign meat (except bacon) and dairy produce.

To remit-

$\frac{3}{4}$ of the tea duty (i.e. $4 \frac{1}{2} d$. per lb.).

$\frac{1}{2}$ of the sugar duty (i.e. $\frac{1}{4} d$. per lb.).

A corresponding reduction on cocoa and coffee (i.e. $1 d$. a lb. on the manufactured article).

Calculating that his remissions would cost the Exchequer 2 2,800,000, Mr. Chamberlain proposed an average 10 per cent. duty on manufactured imports, higher or lower according as the article is more or less finished. 
'The objects in view are :

Objects.

I. The closer union of the Empire by the method of preferential duties.

II. Power to negotiate with foreign countries.

Many estimates have been made as to the charge which would be thrown on the country under the new scheme. We may accept that of the Duke of Devonshire, as given at the Queen's Hall meeting :

'Mr. Chamberlain has calculated to a farthing the cost. effect of his proposals upon the food bill of a working man. I observe he has not taken into his calculations the enhanced cost of all the articles which a working man cannot dispense with, in addition to his food. He has not taken into account the enhanced cost of his house and his clothes, of his boots and shoes, of his household furniture, of his household utensils, of every article which you find in a workman's cottage, every one of which will be enhanced in cost by a 10 per cent. duty on manufactured articles. These calculations going down to a farthing are, I think, subject to some elements of error, but it ought to be more possible to estimate what the whole effect of this new Budget will be to the consumer, to the revenue, and to the Colonies. I do not find any estimate in any of Mr. Chamberlain's speeches of this effect of his Budget. I have endeavoured to make some estimate of its probable result. I cannot give you-there would not be time to give you-the details; but I am prepared to assert, I do not say without fear of contradiction, because I know that I shall be contradicted, but I say it would be a moderate estimate to say that the Glasgow Budget would entail 
a loss to the eonsumer of at least $\mathbf{3 5}$, and possibly $\mathbf{5 0 \text { , }}$ millions or more, in return for which the revenue might gain a gradually diminishing sum, in proportion to the suceess of the scheme, of $\mathbf{8}$ millions a year, and it would provide a subsidy - for it is nothing else-of $2 \frac{1}{2}$ millions to the Colonies.'

Growing demands for pro. tection.

Trade in neutral markets must suffer.

We have not heard the last word from the supporters of the new policy. At protectionist meetings a $5 s$. duty on corn is held to be insufficient. Mr. Lowther has gone as far as $10 \mathrm{~s}$., or even sometimes $\mathbf{1 5 s}$. ' I know perfectly well,' said Mr. Ritchie in a recent speech, "that if this policy were adopted and this shilling were to be given to Canada, it would only be the commencement of a much larger scheme; and I feel now convinced that if the country assents to the imposition of taxes again, however small those taxes may be at the commencement, they will inevitably rise year by year, as they have done both in France and Germany.'

In the interests of commerce are the proposed changes necessary? 'Trade is not dull. And how has our trade been maintained thus far? We have lost ground in protected countries. We have made good the loss in unprotected countries and Colonies. If a door has been partly closed here and there, other openings have been found by British energy and enterprise. The table here given is from the Blue-book.

Observing that the changes in the proportion of manufactured to total exports are mainly due to fluctuations in the value of our exports of coal, what shall be our lesson from these carefully prepared returns? No other country depends as we do on busy and pro- 
sperous trade. Duties on food, if compensated in the rise of wages, duties on raw materials, to be covered

\begin{tabular}{|c|c|c|c|c|c|c|c|c|}
\hline \multirow{2}{*}{ - } & \multicolumn{3}{|c|}{$\begin{array}{l}\text { Principal protected coun- } \\
\text { tries and Colonies }\end{array}$} & \multicolumn{4}{|c|}{ All other countries and Colonics } & \multirow{2}{*}{$\begin{array}{c}\text { Total } \\
\text { to all } \\
\text { coun- } \\
\text { trles anil } \\
\text { Colonies }\end{array}$} \\
\hline & $\begin{array}{c}\text { Foreign } \\
\text { coun- } \\
\text { tries }\end{array}$ & $\begin{array}{l}\text { Colonies } \\
\text { (Canada } \\
\text { and Vlc- } \\
\text { toria) }\end{array}$ & Total & $\begin{array}{c}\text { Foreign } \\
\text { coun- } \\
\text { trieg }\end{array}$ & India & $\begin{array}{l}\text { Other } \\
\text { Colonies }\end{array}$ & Total & \\
\hline $\begin{array}{c}\text { I. Exports of all Articles } \\
\text { of British Produce. } \\
1850 \\
1860 \\
1870 \\
1880 \\
1890 \\
190 J\end{array}$ & $\begin{array}{r}1,000 \\
£ \\
36,180 \\
61.080 \\
94,521 \\
97,743 \\
107,640 \\
115,147\end{array}$ & $\begin{array}{c}1,000 \\
£ \\
3,481 \\
8,639 \\
10,570 \\
11,779 \\
13928 \\
13,276\end{array}$ & \begin{tabular}{c|}
1,000 \\
$£$ \\
39,661 \\
69,719 \\
105,091 \\
109,522 \\
121,568 \\
128,423
\end{tabular} & $\begin{array}{c}1,000 \\
£ \\
15,759 \\
31,146 \\
53,251 \\
50,063 \\
68.521 \\
73,910\end{array}$ & \begin{tabular}{c|}
1,000 \\
$£$ \\
7,242 \\
16,965 \\
19,304 \\
30,451 \\
33611 \\
29,829
\end{tabular} & $\begin{array}{c}1,000 \\
£ \\
8,706 \\
18,061 \\
21,841 \\
33,024 \\
39,801 \\
50,442\end{array}$ & $\begin{array}{c}1,000 \\
£ \\
31,707 \\
66,172 \\
94,490^{\circ} \\
113,538 \\
141,963 \\
154,181\end{array}$ & $\begin{array}{c}1,000 \\
f \\
71,368 \\
135,891 \\
199,587 \\
223,060 \\
263,531 \\
282,604\end{array}$ \\
\hline 1902 & 100,753 & 15,284 & 116,037 & 69,095 & $32,5 \mathrm{C} 3$ & 59,857 & 161,515 & 277,552 \\
\hline $\begin{array}{c}\text { 1I.-Exports of Mannfac- } \\
\text { tnred and partly Manu- } \\
\text { factured Articles. } \\
1850 \\
1860 \\
1870 \\
1880 \\
1890 \\
1900\end{array}$ & $\begin{array}{l}34,842 \\
55,090 \\
81,997 \\
83.401 \\
88,931 \\
82,437\end{array}$ & $\begin{array}{r}3,243 \\
6,895 \\
8,998 \\
9,9 \cdot 18 \\
12,765 \\
12,067\end{array}$ & $\begin{array}{r}38,087 \\
61,985 \\
90,995 \\
93,343 \\
101,696 \\
94,504\end{array}$ & 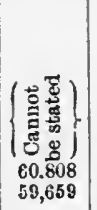 & $\begin{array}{c}-- \\
16,083 \\
18,040 \\
23,112 \\
32,089 \\
28,519\end{array}$ & 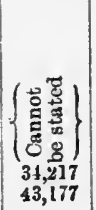 & $\begin{array}{r}28,715 \\
62,915 \\
91,405 \\
104,851 \\
127,104 \\
130,696\end{array}$ & $\begin{array}{r}66.800 \\
124,900 \\
182,400 \\
198,200 \\
228,800 \\
225,200\end{array}$ \\
\hline 1002 & 73,753 & 13,309 & 87,062 & $5 \overline{7}, 905$ & 39,873 & 52,435 & $140,5 \approx 3$ & 227,600 \\
\hline $\begin{array}{c}\text { III.-Pcrecntage whicl } \\
\text { Manufactured and part!y } \\
\text { Manufactured Articles } \\
\text { form of Total Expoi ts } \\
1850 \\
1860 \\
1870 \\
1830 \\
1890 \\
1900\end{array}$ & $\begin{array}{l}96 \\
90 \\
85 \\
85 \\
83 \\
72\end{array}$ & $\begin{array}{l}93 \\
80 \\
85 \\
84 \\
92 \\
91\end{array}$ & $\begin{array}{l}35 \\
89 \\
87 \\
85 \\
81 \\
74\end{array}$ & 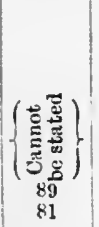 & $\begin{array}{l}\overline{95} \\
93 \\
96 \\
95 \\
95\end{array}$ & 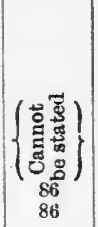 & $\begin{array}{l}91 \\
95 \\
97 \\
92 \\
90 \\
85\end{array}$ & $\begin{array}{l}94 \\
32 \\
91 \\
89 \\
87 \\
80\end{array}$ \\
\hline 1902 & 73 & 87 & 75 & 84 & 95 & 88 & 87 & 82 \\
\hline
\end{tabular}

by a proportionate advance in prices, must damage our export trade. 'The home trade must also suffer. 'The higher the price of commodities, the fewer must be the articles which any given sum can buy. 


\section{CHAP'TER IV}

\section{DUTIES ON FOOD}

Duties on imports fall, as Lord Goschen has shown, on the consumer. Germany-duty on wheat $7 s .2 d$., price $6 s .11 d$. above London. France-duty 12s. $2 d$., price from $11 s$. $3 d$. to $13 s .7 d$. higher than in the United Kingdom. When the corn duties were repealed the effect was immediate. The average price of bread for the five years preceding 1849 was 55s. $5 d$., for the five subsequent years $43 s$. $5 d$.

Food taxes will fall heavily on all consumers, and most heavily on the poorest. Bread becomes the more essential in the ratio of the poverty of the consumer. 'Those on the verge of starvation can give up tea and sugar. They cannot give up bread. At a time when the necessity of promoting the physical vigour of the people is becoming more and more urgent, it is not statesmanship to check the consumption of wholesome food. In the words of Sir Robert Peel : "If there be, from any cause, a tendency to the consumption of articles of the first necessity much more rapid than the increase of population, the responsibility of undertaking to regulate the supply of food by legislative restraints, and the difficulty of maintaining those restraints in the event of any sudden check to prosperity, or increased 
price of subsistence, will be greatly augmented.' So, too, Sir John Gorst: 'A number of those who are now above the poverty line would sink below it, and those already below it would sink yet lower. Free importation of food is vital to the physical and moral well-being of the nation, and is, therefore, at the root of true Imperialism. A great Imperial Power cannot be founded on a starved and degraded population.'

To assume that wages must rise with a rise in prices is opposed to sound theory and to all experience. Never were the wages of our agricultural population so low as when duties were laid on corn, and bread was dear.

It is sought to gain the support of the masses of the people, on whom the burden of duties on food will Wages and cost of food.

chiefly rest, by the promise of more constant employment through the expansion of trade. 'That promise was declared by Lord Goschen, speaking in the House of Lords, to be, in his judgment, unwarranted. 'Who will take the responsibility of saying, "Let us put a tax on food, and I will guarantee that your wages shall be raised"? I say that is a tremendous responsibility, and one which I, for one, would be most reluctant to undertake.'

Viewing our fiscal policy in relation to the cause of Imperial unity, it is evident that the only duties Prosperity which would be effective as against the foreigner would be those on imports of food or raw materials. Great Britain has to face competition abroad. At home we have our submerged tenth. Contrast their condition with the universal prosperity in Canada-a 
young country on the crest of the wave, possessing boundless resources still undeveloped. Read the handbills of the Commissioner of Immigration: 'Plenty of room in Canada for the toilers ;' 'Health and prosperity;' 'Free homes, and 160 acres of the best land in the world given free ;' ' A greater available food-producing area than any other country;' 'Canada's trade and commeree increasing more rapidly than those of any other country;' 'Trade more than doubled in the past seven years;' 'Total imports and exports for $1895, \$ 224,000,000$; total imports and exports for 1903, $\$ 467,000,000$.' Exports ever increasing-of the farm, of the forest, of the mines-everything booming, as in no other country in the world to-day. It is not gencrous to the Mother-country to demand on behalf of this land of plenty that the food of our poorest should be taxed.

Impoverishment of Mother. countrs.

All the burdens of the new policy would be borne by the people of the United Kingdom. The impoverishment of the Mother-land would be fatal to the daughterStates. They would gain indeed by preferential duties on their agricultural produce. They would not gain as much as the Mother-country would lose. The position is fully recognised in Canada. At the Montreal banquet, in connection with the Congress of Chambers of Commeree, Mr. Fisher, Minister of Agriculture, spoke as follows : 'Let me say one more thing, and I say it to the guests from the Mother-land : the sum of agricultural sueeess in Canada is the purchasing power of the masses in the Old Land. It is to you and to your people that we send our surplus. It is through the money received from them that we are prosperous beyond the aspiration 
of our people a few years ago. Anything you do to interfere with the purchasing power of your people would be the deadliest blow at Canada that you could strike. No preference you could give us in your market for the agricultural produce of Canada could make up to us for the decrease in the purchasing power of your people.'

If taxes on food were imposed, the ultimate benefit must accrue to the landlord. It is not thus that the agricultural interest should be promoted. Let us recall the warning words of Lord John Russell in his address to the electors of the City of London. 'I used,' he said, 'to be of opinion that corn was an exception to the general rules of political economy ; but observation and experience have convinced me that we ought to abstain from all interference with the supply of food. Neither a Gorernment nor a Legislature can ever reguiate the corn market with the beneficial effects which the entire freedom of sale and purchase is surc to produce. . . . The struggle to make bread scarce and dear, when it is clear that part at least of the additional price goes to increase rent, is a struggle deeply injurious to an aristocracy which (this quarrel once removed) is strong in property, strong in the construction of our Legislature, strong in opinion, strong in ancient associations, and in the memory of immortal services.'

An impressive warning was once addressed by Mr. Mr.ChamChamberlain to the House of Commons. On August 12, 1881. 1881, he spoke as follows: 'Lastly, sir, is any one bold enough to propose that we should put a duty on food? Well, sir, I can conceire it just possible, 
although it is very improbable, that under the sting of great suffering, and deceived by misrepresentation, the working classes might be willing to try strange remedies; but one thing I am certain of-if this course is ever taken, it would be the signal for a state of things more disastrous than anything which has been since the repeal of the Corn Laws. $\boldsymbol{A}$ tax on food would mean a decline in wages. It would mean more than this, for it would raise the price of every article produced in the United Kingdom, and it would indubitably bring about the loss of that gigantic export trade which the industry and energy of the country, working under conditions of absolute freedom, have been able to create.'

Mr. Chamberlain is now the leader of a movement in support of the policy he once condemned with arguments of unanswerable force. We have examined the progress of trade in the light of the leading statistics. The increase in volume has been continuous. The proportion of our exports to foreign countries and to British possessions has remained to a fraction the same. In comparison with foreign countries per head of our population we continue by a long way to lead. To go back from free trade to protection would be ' against all the signals.' 


\section{CHAPTER V}

FISCAL UNION OF THE EMPIRE

IT has been aśsumed in recent discussions that new fiscal advantages have been offered by the Colonies. No proposals have come, or are likely to come, through authorised channels. Fiscal policies must be determined with reference to the conditions with which Governments have to deal.

I. Colonial Governments depend on revenue from Customs. More than half the revenue of Canada is derived from this source.

Fiscal policy of the Colonies.

II. It is the aim of every civilised country to give variety of opportunity to every class and every aptitude.

The Colonies are resolved to establish manufactures; they judge it unwise to depend wholly on agriculture and mining. It would be in a special sense unwise on the part of Canada, where outdoor employment, except in lumbering, is suspended in winter. State aid is necessary everywhere for industries in the early stage. Bounties are less objectionable than tariffs.

In Canada, under the liberal policy inaugurated in Canada. 1899, a preference of $33 \frac{1}{3}$ per cent. has been given to Great Britain. On manufactured articles, which alone we are able to supply, the reduced duties average 25 per cent. The raw materials, drawn from the United States, 
are admitted into Canada free of duty. The result is as under :-

\section{Imports into Canada (Pencentages)}

Before preference:

$$
\begin{gathered}
\text { From } \\
\text { United Kingdom }
\end{gathered} \text { United States }
$$

Average of years $1893-7 \ldots \ldots$

32

49

After prefercnce :

$\begin{array}{ll}1898 \ldots \ldots \ldots . & 25 \\ 1902 \ldots \ldots \ldots . & 25 \\ 1903 \ldots \ldots \ldots & 26\end{array}$

Memorandum by Canadian delegates.

The policy of the Canadian Government was explained in the memorandum submitted by the delegates to the Conference held last year. The necessitics of the country require the admission free of duty of raw materials, machinery, and tools. These articles are supplied from the United States. The textile goods which Great Britain could supply are largely manufactured in Canada. 'Canadian manufacturers naturally expect a share of the home markets, and, as their establishments develop, they correspondingly expect a larger share.' 'The delegates claimed that ' an advantage has been given to the British manufacturer. . . . If he has not availed himself of it, the fault is not that of the Canadian Government or the Canadian fiscal policy.'

Sir Wil.

frid

Sir Wilfrid Laurier's speech at the Congress of the Laurier. Chambers of Commerce of the Empire, lately held at Montreal, is perhaps the most important expression of Colonial opinion, as yet delivered sinee the reversal of our fiscal policy has been under discussion. 'As far as Canada was concerned, they were intensely desirous of having a preferential market for food products in Great Britain ; but they did not want to force their views. . . . If further concessions were to be made by Great Britain 
they must be mutually profitable.' No reductions of tariff were proposed by Sir Wilfrid Laurier. He said it would take him too far into politics.

We have a recent declaration of the views of Canadian Canadian manufacturers. At a banquet given at turers. 'Toronto, on November 19, by the Canadian Manufacturers' Association, Mr. Drummond, president of an organisation representing fifteen hundred manufacturers, spoke as follows: "We favour a policy of reciprocal trade with the Empire by means of preference against foreign States. Canada must, however, necessarily provide under all conditions that the minimum tariff should afford fair protection to Canadian producers, so that the high standard of wages and living may be retained on a parity with the wages paid in the United States.'

In Australia Mr. Deakin supports Mr. Chamberlain's Australia. proposals. He has made no sign in the direction of a reduction of duties on British goods, and he is favourable to bounties for the encouragement of the home industries of Australia. While in Victoria I frequently discussed the question of tariffs with Sir George Turner, then Premier of the Colony, now Finance Minister under the Commonwealth Government. As in Canada, so in Australia, preference seemed only possible by increasing the duties on foreign goods. Free admission even of British goods could not be conceded. In all the self-governing Colonies, industries imperfectly organised need protection. The recent elections to the Commonwealth Parliament give no indications of a change of policy.

The Cape and Natal have recently agreed to a 25 per Cape and 
cent. preference to British imports. They have no manufacturing industries.

Mr. Cham. berlain's protest.

Mi. Chamberlain has always protested against any one-sided bargain. In November 1896 he said: 'This proposal [for Imperial reciprocity] is in effect that, while the Colonies should be left absolutely free to impose what protective duties they please, both on foreign imports and upon British commerce, they should be required to make a small discrimination in favour of British trade, in return for which we are to impose duties on food and raw material. There is not the slightest chance that in any reasonable time this country, or the Parliament of this country, would adopt so onesided an agreement. The foreign trade of this country is so large, and the foreign trade of the Colonies is comparatively so small, that a small preference would be but a slight benefit. I do not believe that the working classes of the country would consent to a revolutionary change for an infinitesimal gain.' At the Conference last year the second over which he had presided, Mr. Chamberlain said: 'While I cannot but gratefully acknowledge the intention of this proposal, and its sentimental value as a proof of goodwill and affection, yet its substantial results have been altogether disappointing. . . . So long as a preferential tariff, even a munificent preference, is still sufficiently protective to exclude us from your market, it is no satisfaction that you have imposed even greater disability upon the goods from foreign markets.'

Fiscal independ. ence.

Sir Wilfrid Laurier has consistently asserted the right and the duty of the self-governing Colonies to maintain their fiscal independence. At a farewell 
banquet in Liverpool at the close of the Colonial Conference of 1897, he appropriately quoted Rudyard Kipling: 'Daughter am I in my mother's house, but mistress in my own.' Those words, he said, expressed truly the Colonial sentiment. The Colonies have the pride of British connection and Imperial unity; they have not less the pride of local autonomy and the pride of legislative independence.

In his speech at Montreal, Sir Wilfrid Laurier was equally emphatic: 'If we are to obtain concessions from Great Britain by a surrender of our political rights, I would say, Go no further. Even for the maintenance of the British Empire, it would be a most evil thing if any of the Colonies were to consent to surrender any of their legislative independence.' All British statesmen are in agreement with the Canadian Premier. We could not ask for the surrender of an independence too long and too fully conceded to be now recalled. No self-governing Colony would consent to put fetters on the enterprise and industry of its people. In the words of Adam Smith, "To prohibit a great people from making all that they can of every part of their own produce, or from employing their stock and industry in the way that they judge most advantageous to themselves, is a manifest violation of the most sacred rights of mankind.'

As Canada gains in population and wealth, changes in the relations with the Mother-country are inevitable. power. Sir Wilfrid Laurier's speech at Liverpool may again be quoted: "At the present time, so far as I know, in the Colony which I represent we are entirely satisfied with the relation that we have. We have our local auto- 
nomy, and that is the first thing with us. We all feel, however, that the time may come, and that the time must come-there is no use in disguising it - when the existing relations, though they may be satisfactory at the present moment, will be inadequate for the future development of the Colony.'

The Alaska Boundary award may lead to a demand for more independent treaty-making powers. We are ready to concede self-government in the widest sense. We could not undertake to enforce the observance of a treaty in the negotiation of which we had not been consulted.

Possible expansion of British trade with the selfgoverning Colonies.
To what extent is it possible that British exports to the Colonies should be increased under a preferential tariff? Let us turn to the Blue-book. It contains the following memorandum on Colonial trade :

The year chosen for examination is 1900 , the latest year for which full details for each Colony have been published by the Board of Trade.

The general result of the analysis for all the self-governing Colonies is as follows:

The value of the imports of merchandise from all sources into the self-governing Colonies in 1900 was 113 million pounds, of which 55 millions were imported from the United Kingdom, 47 millions from foreign countries, and 11 millions from other British possessions.

Of the total imports from foreign countries, nearly two-thirds (29 millions) are accounted for by Canada, and nearly a quarter (11 Natal, and New Zealand.

About $9 \frac{3}{4}$ nillions' worth of the imports from foreign countries are of a class not produced in the United Kingdom, and about $8 \frac{3}{4}$ millions' worth consist of articles which, though produced in the United Kingdom, we cannot expect to export to the Colonies in competition with similar foreign and Colonial goods (e.g. wheat, meat, timber, butter, \&c.).

After dedueting the above, there remain imports from foreign countries to the value of about $28 \frac{1}{2}$ millions. Of this amount about 
16 millions are accounted for by Canada, 8 millions by Australia, and 2 millions by the Cape.

Adding $3 \frac{3}{4}$ millions for foreign goods imported into the Colonies through the United Kingdom, we arrive at a final total of about 32 millions sterling for the goods imported into the Colonies, in the supply of which the United Kingdom might possibly take a larger part.

The two tables below-both dealing with the year Board of 1901-have been issued by the Board of 'Trade.

I

Imports of the Self-govenning Colonies, 1901

\begin{tabular}{|c|c|c|c|c|}
\hline Colony & & Total imports & $\begin{array}{l}\text { Goods imported } \\
\text { from for eign } \\
\text { counties }\end{array}$ & $\begin{array}{l}\text { Liberal estimate } \\
\text { of goods imported } \\
\text { from foreign } \\
\text { conutries which we } \\
\text { might supply }\end{array}$ \\
\hline \multirow[t]{2}{*}{$\begin{array}{l}\text { Australia } \\
\text { New Zealand } \\
\text { Natal } \\
\text { Cape of Good Hope } \\
\text { Canada } \\
\text { Newfoundland . }\end{array}$} & 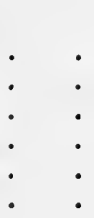 & \begin{tabular}{r}
\multicolumn{1}{|}{} \\
$41,502,000$ \\
$11,353,000$ \\
$9,556,000$ \\
$21,416,000$ \\
$58,414,000$ \\
$1,513,000$
\end{tabular} & $\begin{array}{r}\qquad \\
12,436,000 \\
2,018,000 \\
1,554,000 \\
4,367,000 \\
28,821,000 \\
473,000\end{array}$ & $\begin{array}{r}\qquad \\
\qquad \\
9,000,000 \\
1,500,000 \\
750,000 \\
2,000,000 \\
10,000,000 \\
200,000\end{array}$ \\
\hline & & $123,754,000$ & $49,669,000$ & $23,450,000$ \\
\hline
\end{tabular}

II

Imports of Food, Raw Materials, and Manufactures

\begin{tabular}{|c|c|c|c|c|}
\hline & $\begin{array}{l}\text { Food and } \\
\text { driuk }\end{array}$ & $\underset{\substack{\text { Raw } \\
\text { matcrials }}}{\text {. }}$ & $\begin{array}{l}\text { Manufacturet } \\
\text { articles }\end{array}$ & Totals \\
\hline 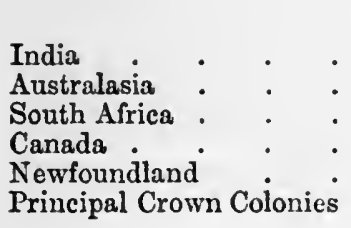 & $\begin{array}{c}£ \\
\qquad, 270,000 \\
2,628,000 \\
2,535,000 \\
7,253,000 \\
268,000 \\
6,614,000\end{array}$ & 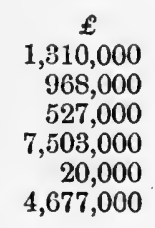 & $\begin{array}{r}\stackrel{£}{£} \\
9,851,000 \\
10,858,000 \\
2,859,000 \\
14,065,000 \\
185,000 \\
4,242,000\end{array}$ & $\begin{array}{r}\stackrel{f}{\mathfrak{E}} \\
14,431,000 \\
14.454,000 \\
5,921,000 \\
28,821,000 \\
473,000 \\
15,533,000\end{array}$ \\
\hline & $22,568,000$ & $15,005,000$ & $42,060, \mathrm{COO}$ & $79.633,000$ \\
\hline
\end{tabular}


In Canada the United States has the advantage. In all other Colonies the Mother-country has the lion's share. Holding, as we do, so commanding a position in the Colonial markets, it is evidently impossible by any changes of tariff largely to increase our exports of manufactured articles; and the interests of the Motherland and the self-governing Colonies in matters of trade are necessarily conflicting.

Lord

Salisbury on tariffs.

The difficulties of fiscal union with the Colonies were plainly stated by Lord Salisbury in reply to a deputation from the United Empire 'Trade League. 'If,' he said, ' you give preferential treatment to your Colonies, it must be that you tax the similar goods from the rest of the world, and that the Colonies are to command a better price for their goods than they would obtain under unrestricted competition. A better price for the vendor means a more disagreeable price for the consumer, and we have to receive proof that the people of this country are in favour of a policy of preferential taxes on wheat, on corn, and on wood.' A bargain, on mutually satisfactory conditions, is impossible between a country seeking to increase her exports of manufactures and a country chiefly concerned to protect her industries.

Nor is it possible to set up an imperial customs union on terms which would be just and equal to all. India, Australasia, South Africa, Canada, and the United Kingdom differ essentially in climate, in soil, in products, in population. The difficulties experienced by the Australian Commonwealth in framing a common protective tariff for the six States should be a warning against any attempt for the Empire. 
A common tariff for the British Empire is, as we have said, impossible. That truth was recognised long ago by Turgot, a statesman of far-seeing wisdom-wiser than the age in which he lived: ' $\mathrm{Je}$ crois fermement que toutes les métropoles seront forcées d'abandonner tout empire sur leurs colonies, de leur laisser une entière liberté de commerce avec toutes les nations, de se contenter de partager avec les autres cette liberté, et de conserver avec leurs colonies les liens de l'amitié et de la fraternité. Si c'est un mal, je crois qu'il n'existe aucun moyen de l'empêcher; que le seul parti à prendre sera de se soumettre à la nécessité absolue et de s'en consoler.'

'The Colonies cannot complain that their present position is disadvantageous. To all her Colonies Great Britain is, beyond comparison, their best customer. In Advantages enjoyed by 1902 we took $£ 107,000,000$ of imports from British possessions, and the amount imported annually is ever increasing. Of Canada's total exports of her produce Great Britain purchases $\mathbf{5 5 \cdot 7}$ per cent., the United States 34 per cent., Germany only $\cdot 7$ per cent., and other countries 9.6 per cent. The exports to the Mother-country provide the means of paying for the excess of imports in the trade with the United States. The self-governing Colonies put high duties on imports from the Mother-country. We admit their exports duty free.

The Colonies have one-fifth of the commerce of the Empire, one-fourth of the population, and much more than one-half of the revenues of the Mother-country.

We spend between $£ 60,000,000$ and $£ 70,000,000$ annually on Imperial defence. To naval expenditure 
we receive no contribution from Canada-a small sum only from the other Colonies in comparison with the total amount. 'The military expenditure of the Colonies is not onc-tenth of that incurred by Great Britain.

Lord

Goschen.

Let us not insist further on preferential tariffs. In his speech in the House of Lords in June last, it was finely said by Lord Goschen: 'Is it fair to put the mandate before the people-No preference; no empire? I think that would be unjust to the people of this country and to the people of the Colonies. . . . Surely it is not to depend simply upon a commercial bargain with the Colonies. Without commercial bargains the Colonies have lavished their blood in South Africa, and we have lavished our millions in the protection of the Empire, asking but little in return. Under these circumstances I am not to be told that if we cannot accept this plan we are to accept the fate of a dying Empire. 'The resources of statesmanship are not, I hope, exhausted.' SirGeorge When all that is possible has been done to advance
Bowen. material interests in a time of national stress and strain they are as nothing beside the racial sympathies. In the words of Sir George Bowen, a former Governor of Victoria: "The people of the Mother-land and the selfgoverning Colonies are one great homogeneous people, one in blood, in language, religion, and laws-dispersed, indeed, over a boundless space, and yet held together by strong moral ties.' In the present age, with the increased and increasing facilities of communication, even political unions may exist on a vaster scale than were possible in former days.

Diamond
Jubilee. There was no fear of separation during my residence 
of five years-five happy years-in Australia. Nowhere could we look for more loyal demonstrations than were made on the occasion of the Diamond Jubilee of her late Majesty. The Irishmen were conspicuous with their green scarves in every procession. I was serving in Australia when the first contingents were despatched to South Africa, I was an eye-witness of those moving scenes. There was the same disinterested patriotism, the same loyalty to the old flag, in freetrade Sydney as in protectionist Victoria. These sentiments did not spring from tariffs. When the reverses came in South Africa, and the Empire needed help from all her sons, with one heart and one voice they responded to the call. 'They were moved by no sordid considerations-Amor patrice ratione valentior. The people had carried into their new homes beneath the Southern Cross an undying love for the old home. They were inspired by the same feelings which, in an early age of the world, were kindled in the Greek Colonies by the sacred fire, brought from the parent State and kept for ever burning.

The benefits of their British citizenship to distant Colonies were acknowledged in fitting terms in an Colonial Conferaddress presented to the late Queen by the delegates to the first Colonial Conference in 1887: "Your Majesty's reign has, under Divine Providence, endured for half a century; and, amidst revolutions and changes of dynasty and of systems of government in other countries, the principles of the laws of your predecessors for a thousand years still offer your subjects that safety and prosperity, and the Empire that stability, which claim the admiration of the world.' 
The delegates concluded their address with the prayer that the Queen's throne might remain established in the land in justice and righteousness for generations to come. Our lamented and venerated Queen has been called to her rest, and her son now reigns in her stead. 'The King is rendering signal services to the Empire, and chiefly in the cause of peace abroad and loyal contentment at home. His recent visits to Portugal, Italy, and to the French Republic have had a magical effect. No Minister could have accomplished what the King has done. He could not have spoken as the King speaks - in the undivided name of all his people. Nor should the auspicious journey of the Prince and Princess of $W$ ales be forgotten in this connection. It will long live in the memory of our fellow-subjects beyond the seas.

Melboume Argis.

Ottawa Confer. ence.
The bonds which unite us do not depend on personal associations. A leading journal-the Melbourne Argushas described in glowing language Australian sentiment: "The words and deeds of the young Australians who have grown up out of sight and touch of the Mother-country belie the notion that disruption has any place in their thoughts. Never a breath of trouble stirs in the old land but the pulses of Australians beat faster and the resolute pride of race mounts higher. Talk of contemplated severance can only be treated as idle vapouring.'

Four out of five of the people of Canada are native-born. We have the testimony of my valued friend Dr. Parkin that the fact has not weakened in the slightest degree the closeness of sympathy with Great Britain and the Empire.

At the opening of the Ottawa Conference, Canadian 
sentiment was eloquently expressed by the Premier, Sir John Thompson, a statesman whose loss was deeply felt in Canada and in England. 'On this happy occasion,' he said, 'these delegates assemble after long years of self-government in their several countriesyears of greater progress and development than the colonies of any empire have yet seen in the past. We have met not to consider the prospect of separation from the Mother-country, but to plight our faith anew to each other as brethren, and to plight anew with the Mother-land that faith which has never yet been broken and tarnished.'

Britain's myriad voices call,

Sons, be welded, each and all,

Into one Imperial whole.

One life, one flag, one fleet, one throne,

Britons, hold your own.

The bonds of race are not restricted by the boundaries of States. All English-speaking men should be a band of brothers. 'The co-operation of the two great comRelations with United munities of English-speaking men would bring together not merely the people of these small islands and of our Colonial fellow-subjects. It would bring together the two great branches of the English-speaking race. The attainment of such an ideal must be the work of time. It should never be absent from the minds of British statesmen. 


\section{CHAPTER VI}

\section{RETALIATION}

Sir

Edward Grey.

Retaliation is a policy of the last resort, to which recourse should be had only under conditions such as were recently laid down by Sir Edward Grey: 'He could imagine a case in which some foreign country might mete out to us treatment that was so obviously hostile and unfair that it would be impossible for us to sit still under it; but before he resorted to retaliation he would ask to have five things proved to him clearly. The first was that there was such a case of hostile treatment on the part of a foreign country; the second was that all the resources of ordinary diplomatic negotiation had been exhausted; the third, that commercial reprisals would not hurt us more than they would hurt the other country; the fourth, that they were likely to be effective; and the fifth, that there was no other or better way of bringing pressure to bear to obtain our ends.' As Mr. Arthur Elliot, not the least able of the Ministers who have lately resigned, has shown, we are free to consider every case on its merits.

Mr.

The policy of the British Gorernment was explained Balfour. by Mr. Balfour at Sheffield. It is no new policy. If a country does us grievous injustice we are bound to consider our own interests. Free trade is not altruistic. 
It is enlightened self-interest. Mr. Balfour was careful to explain that retaliation must be applied with discretion. We must do no injury to ourselves. We may recall a passage from Adam Smith: "There may be good policy in retaliations when there is a probability that they will secure a repeal of duties. To judge Adam

Smith on retaliation. whether such an effect is likely to be produced belongs to that insidious and crafty animal, the statesman or politician. When there is no probability of securing a repeal of duties, it seems a bad method of compensating some classes to do injury ourselves to other classes.'

In a former speech at Sheffield, in November 1896, Mr. Balfour met the demands of the fair traders with Mr. Balfour, 1896. a lucid explanation of the course of trade. 'A great foreign export trade carries with it as a mathematical consequence a corresponding import trade. If it be desired that the export trade should be a great trade, there must be an import trade to pay for it. We must be paid in goods-we can be paid in nothing else; and we must not only be paid in goods for what we export, but we must be paid in goods for the interest on the capital which we have invested abroad. It would be unreasonable to be alarmed at the growth of manufactures by foreign countries. That growth is inevitable. Like it or dislike it, let us not grumble at what is really the result of inevitable laws.'

The new fiscal policy has been commended to the Protection working man, even by officials in positions of responsibility, on the assumption that the less we import from will not raise wages. the foreigner the more constant must employment be at home, and the higher the rates of wages. The answers to such fallacies should be made plain to every 
elector. Trade is exchange. We do not pay in silver and gold. We pay in goods and services. International trade is on the basis of exchange of commodities. The movements are obscured to the ordinary observer in the vast volume and extent of the transactions. Retaliation cuts both ways. No other country compares with the United Kingdom as an exporter of manufactured goods. No other country is equally concerned in keeping the door open.

Russia. A flying survey of our trade will show that, under present conditions, England must be loser in a war of tariffs. We should begin with the countries which levy the heaviest duties. In Russia the duties on imports of British goods are no less than 131 per cent. Here, if anywhere, retaliation is justified by the treatment we receive. Would it help us? Let us compare the imports of manufactures on both sides for the year 1902. Our imports from Russia were valued at $£ 26,000,000$, consisting, according to a classification by Mr. Sydney Buxton, of the following items :

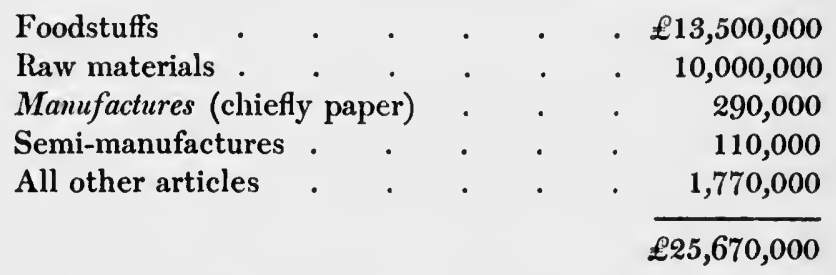

Our exports of manufactures to Russia in 1902 were

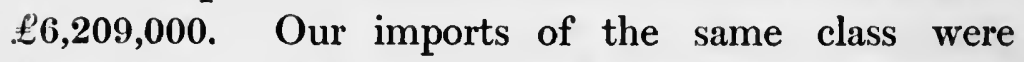

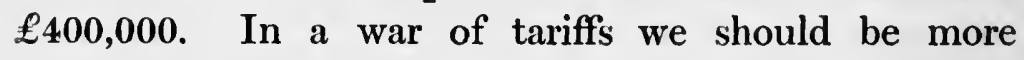
vulnerable than Russia.

United States.

Turn to the United States. Duties of no less than 73 per cent. are levied on some British goods. Our 
imports in 1902 were $£ 127,000,000$-a vast excess orer exports. Was the trade unprofitable? Would retaliation help us? Of manufactures we imported to the value of $£ 9,300,000$, of semi-manufactures-chiefly leather-£3,900,000. Even the machinery we import-to a limited extent-from America is an aid to British labour. It makes it more efficient. The great bulk of our imports consisied of food and raw material. We could not exist without these cheap and abundant supplies. And how is the balance of trade adjusted? Not in gold and silver. In the four years 1899-1902 we imported of the precious metals from the United States to the aggregate value of over $£ 46,000,000$. We sent to the United States the insignificant sum of $£ 125,000$. The excess of our imports was represented by payments for freights to British shipowners, by dividends on investments, by importations of tropical products supplied by British merchants.

British exports of manufactures to the United States are increasing: $1901, £ 15,275,000 ; 1902$, £19,468,000. Exports of manufactures from the United Kingdom to the United States being largely in excess of imports, is it policy to enter upon a tariff war? In America the opinion grows that the McKinley tariff is too protectionist. It has favoured over-capitalised trusts and combines. Individuals have amassed portentous wealth. Trades, highly protected, have enjoyed an excessive but ephemeral prosperity. The consumer has been heavily burdened. If wages are high, the cost of living is excessive. It would be wise to take no action on our part which might check the movement in favour of more freedom for trade. In a war of tariffs we should 
be the greater sufferers. In the vast trade with the United States every transaction is for our advantage. We shall injure ourselves if we throw impediments in the way.

France. Let us tum to our nearest neighbour. In France, the duties levied on British imports are 30 per cent. Our direct imports much exceed our exports. How is the balance adjusted? Our most important import from France is silk; value in 1902, $£ 9,560,000$. Our exports of silks to France are about $£ 400,000$. The course of trade is less disadvantageous to England than at first sight appears. We export manufactures to India, China, and tropical countries. We take in exchange jute, raw silk, indigo, coffee, rice-in short, all that varied tropical produce, the consumption of which, in France as in all highly civilised countries, is ever increasing, the demand being largely met by consignments through British merchants. Our trade with France is an exchange of manufactures for manufactures by a triangular route. The exclusion of French silks would diminish the quantity of English goods now sent, directly or indirectly, to France. We pay for all that we take from the foreign producer in something to which we can apply our capital and labour to more advantage.

It may be said, ' The money now spent on imported silks would be spent on something else, on which English labour and capital would be employed.' Yes, but less profitably employed. The French beat us as manufacturers of silk. We do better in other lines. We might not have consented to all the conditions of the treaty negotiated by Mr. Cobden if we had fore- 
seen that there would be no reciprocity. To recall what has been done is more difficult.

Retaliation and exclusion are not a new policy with foreign nations. In the same decade of the last century in which Sir Robert Peel was engaged in inaugurating the free-trade system under which our country has so greatly prospered, my father was constructing the first lines of railway made in France-those connecting Paris with Rouen, Havre, and Dieppe. So prohibitory were the French tariffs that the duty on rails imported from England exceeded the first cost. 'There were no mechanical works in France capable of turning out a locomotive engine; yet the import duties were so high that it was necessary to create a new establishment at Sotteville, near Rouen, where all locomotives and rollingstock for the railways were made by English and Scotch mechanics, some 600 of whom were employed. As formerly in France the pioneers of railways set up industrial establishments-to avoid the payment of oppressive duties of Customs--so now in Russia factories are established with 13ritish capital to escape duties on cotton goods on a prohibitory scale.

Let us examine the probable effects of retaliation Germany. on our trade with Germany. Twenty-five per cent. duties are levied on British manufactures. If the scale is lower than in the case of Russia, the United States, and France, Gcrmany stands less in need of protection. As the largest manufacturer of the cheap goods in demand in the Colonies and the neutral markets of the tropics, and as the chicf exporter of manufactured and half-manufactured articles into our home markets, Germany is everywhere our most serious competitor. 
Great and Greater Britain are, however, the best customers for German goods. We have therefore in hand at all times the power to bring pressure to bear.

The Colonial Premiers who took part in the Conference of last year knew well that they had in their hands 'a revolver' quite as formidable as that with which the United Kingdom is armed. The report of the proceedings gives their views as follows: 'In connection with the discussion of preferential trade, the Conference considered the point raised by the Commonwealth Government as to the possibility of the Colonies losing "most favoured nation" treatment in foreign countries in the event of their giving a tariff preference to British goods. As, however, the exports from the Colonies to foreign countries are almost exclusively articles of food or raw materials for various industries, the possibility of discrimination against them in foreign markets was not regarded as serious; and as the exports from foreign countries to the Colonies are mainly manufactured articles, it was recognised that, if such discrimination did take place, the Colonies had an effective remedy in their own hands.'

By hostile tariffs we may exclude German goods. Our part in the supply of the home demand in Germany can never be large. It is vital to the people to manufacture for themselves. 'The increase in the urban population-depending entirely upon industrial occupations-is more rapid than with us. Germany has not yet found an outlet for her products, such as we have in the neutral markets of India, the tropics, and the Colonies.

It is agreed that the raw materials of our industries 
must be admitted free. The steel billets supplied at a price below cost, and of which it was estimated that we might take not less than one million tons in 1903, are the raw material for metal wares, tools, and machinery. As Lord George Hamilton has shown, the tendency grows to import into this country manufactures in the less advanced stage, and to work them up into articles in the production of which more highly skilled and better paid labour is employed. This is not a trade that we should desire to check.

Putting out goods abroad at prices below those charged at home is unpopular among the working classes. In Germany it has produced strong comments in the Diet, and is now the subject of parliamentary inquiry. In the United States a similar inquiry has been held. It was shown that foreign customers were supplied with American goods at prices 20 per cent. lower than in the home market. Such a state of things cannot long be suffered to continue. Consumers will resent the selfishness of protected interests. Let us leave these influences to their natural course. It will help us more than a policy of retaliation.

Dumped goods are objectionable, because a trade which is unremunerative cannot be permanent. Sooner or later such supplies must cease. Meanwhile, it may be policy to take advantage even of precarious resources. If we reject the cheap raw materials which Germany is ready to give, they may be used to our disadvantage in Belgium and other countries with which we compete.

The Select Committee on Tariffs, of 1840 , were select opposed to protective duties in any form. "They 
impose upon the consumer a tax equal to the amount of the duties levied upon the foreign article, whilst they also increase the price of all the competing homeproduced articles to the same amount as the duty, but that increased price goes, not to the 'Treasury, but to the protected manufacturer. It is obvious that high protective duties check importation and consequently are unproductive to the revenue, and experience shows that the profit to the trader, the benefit to the consumer, and the fiscal interests of the country, are all sacrificed when heary import dutics impede the interchange of commodities with other nations.'

While holding strongly to free trade, as the best policy for all nations, and in a special sense for the United Kingdom, it is not contended that the power we possess, as the best foreign customer of every industrial country, should never be used. There may be cases where we should gain on the whole by refusing to buy at prices below the fair cost of production. It is well that our rivals should see that we are watchful over our own interests. It is evident that our recent discussions on fiscal policy have been followed with anxiety. We hear nothing more of the exclusion of British self-governing Colonies from the privileges of the most favoured nation. 


\section{CHAP'TER VII}

FREE TRADE

THE general arguments in favour of free trade were sir Robert presented to Parliament by Sir Robert Peel in his Free great speech of January 1846 in the House of Trade. Commons. He had no guarantee, he said, that other countries would follow our example. 'Wearied with long and unavailing efforts to enter into satisfactory commereial treaties with other nations, they had resolved at length to consult their own interests, and not to punish those other countries for the wrong they were doing us in continuing their high duties by imposing high duties ourselves. It might be asked, what is this superfluous liberality? It was true that foreign countries which had benefited by our relaxation had not followed our example-nay, had applied to the importation of British goods higher duties. What had been the result? Our export trade had greatly increased. And why? Because these very precautions against the ingress of our commodities were a burden, and the taxation, inereasing the cost of production, disqualified the foreigner from competing with you. By the remission of your duties upon raw material, by inciting your skill and industry, by competition with foreign goods, you have defied your competitors in foreign markets, and you have even been able to exclude them.' 
Special conditions with which we in England have to deal.

Looking back to the beginning of last century, we see in the early years a dull and unprogressive condition. Since the adoption of a free-trade policy England has been in the van. If we make a retrograde step the protectionist movement everywhere will be stimulated. 'The flow of commerce will be arrested. A bond of union between nations will be weakened. Political consequences may follow which the whole civilised world may have reason to deplore.

We must never forget the special economic conditions with which we have to deal.

I. We have built up on the system of free imports a gigantic and complicated industrial fabric, on a scale never yet reached in any other country.

II. We are compelled to import by far the greatest proportion of our foodstuffs and raw materials.

A nation whose industrial fabric has gradually adjusted itself to protection may add to or manipulate its tariffs without serious risks of disturbance. Our population has multiplied in dependence on cheap supplies. We cannot return to protection, nor by tariffs raise the price of our imports from our Colonies, without a dangerous disturbance of all the adjustments. Free-trade has not enabled the United Kingdom to manufacture for all the world. It has secured supplies of food and raw materials at the lowest prices, and made the United Kingdom the pivot of commerce and finance.

Mr. Mr. Felix Schuster, Governor of the Union of Schuster. London and Smith's Bank, in his speech at the halfyearly meeting on July 29, 1903, dealt with the fiscal policy from the standpoint of the merchant and the 
banker. 'London,' he said, ' was admittedly the banking and financial centre. Go where they would, a bill of exchange was the one medium of exchange which always had a ready market. A bill on London was created in every part of the globe. There was always a seller because goods were shipped here; there was always a buyer because goods were obtained from here, because our ports were free, because our doors were open to the trade of the whole world. It was through being the centre of the world's commerce that we had become the world's clearing-house, that our money market had been the cheapest in the world; this in its turn had enabled us to find for our Colonies and for foreign nations cheap capital for the development of their industries. Second only in importance to our supremacy as international bankers, another interest which must be most carefully safeguarded was our position as the carriers of the world. The whole economic condition of this country depended on the supremacy and maintenance of our shipping industrya supremacy which appeared to have been attained only through our trade relations with all parts of the world.'

In all countries which have adopted protection, its influences on Parliament have been deteriorating. Mr. Winston Churchill has described the new party which Effects of monopoly in protectionist would arise, rich, matcrialist, and secular. In and out of Parliament every monopolist would be eager to push his special trade. Every producer would clamour for a better price. Prices could be raised by tariffs, and pressure would be used. Few will be sufficiently far-sighted to see that the higher the price the less must be the demand; and that a larger business with small profits 
may be more profitable than fewer sales at a higher profit. Nor could retaliation, onee adopted, be abandoned. Interests depending on protection would have been ereated, and we could not do them injury without compensation.

Undue reliance on tariffs.

Over-pro-

Home competi. tion. duction.

Protection tends to turn the employers and the workers from the legitimate means and sourees of prosperity. Technical instruction, inventive skill, effective labour with the hands, and careful administration, will be neglected.

Protection leads surely to over-production. If we exclude foreign iron and stecl, the price of British iron and steel will rise, profits will advanee, the home production will be artificially stimulated, the markets will be glutted. We shall experience the troubles which have, on a colossal scale, befallen the Steel Combine of the United States.

Retaliation will not relieve our merchants and manufacturers of the pressure of competition. The most severe is that of their fellow-countrymen. The home competition is more intense than that of the foreigner. In no branch of enterprise is our ascendency more undisputed than in shipping. In none is the Shipping. competition so keen and returns so uncertain. Some outward coal freights from Cardiff may be quoted:

\begin{tabular}{|c|c|c|c|c|c|c|}
\hline & & 1903 & 1902 & 1901 & 1900 & 1898 \\
\hline To- & & s. d. & 8. d. & s. $d$. & 8. d. & $d$. \\
\hline Alexandria. & . & 46 & 54 & 78 & 122 & 100 \\
\hline Barcelona. & - & 59 & 69 & 711 & 118 & $1010 \frac{1}{2}$ \\
\hline Genoa & . & 40 & 55 & 69 & 104 & 89 \\
\hline Malta. & 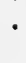 & ${ }^{3} 6$ & $f^{4}{ }^{4}$ & $f^{5}{ }^{9}$ & $f^{4}$ & ${ }_{f}^{8}{ }^{4}$ \\
\hline & • & 5.50 & $6 \cdot 64$ & $7 \cdot 97$ & $12 \cdot 14$ & $11 \cdot 0$ \\
\hline Port Said & - & 46 & 54 & 74 & 121 & 93 \\
\hline
\end{tabular}


We have an experience of the management of ships such as no nation possesses, yet depression recurs again and again. The fluctuations in the business of the shipbuilder are duc to reckless over-building. In 1881 1883 the tonnage built in the United Kingdom rose from 608,878 to 892,216 . In 1886 and 1887 the tonnage built fell to 331,528 and 377,198 . With less tonnage on the berth, freights improved. Inflation rapidly followed. The tonnage built for 1889-1892 exceeded 800,000 annually. A decline followed. 'The boom in shipping caused by the South African war led to a renewed excess in building, and for 1899-1902 the tonnage builtaveraged 956,700 tons. A collapse in freights was inevitable. It was not due to foreign competition.

Protection has not assured uninterrupted prosperity in Germany. In his speech at the Queen's Hall, Lord Goschen referred to shipping and maritime enterprise. The dividends of the chief companies showed a reduction all along the line-in the case of the HamburgAmerican Line from 10 per cent. in 1900 to $4 \frac{1}{2}$ per cent. in 1902 ; for the North-German Lloyd $8 \frac{1}{2}$ per cent. in 1900 ; no dividend in 1902.

Tariff wars never succeed. Witness the recent Tariff experiences in Russia, Germany, France, and Italy. From 1888 to 1898 a war of tariffs was waged between France and Italy. The trade between the two countries fell during the struggle from over $£ 19,000,000$ to $£ 10,500,000$ a year. The conclusion of peace brought some mutual concessions, shared, however, by Great Britain, as entitled by treaty to the privileges of the most favoured nation. The Russo-German war of tariffs continued from 1892 to $\mathbf{1 8 9 5}$. The trade 
between the two countries fell from $£ 35,200,000$ to $\mathfrak{2 6 , 7 7 0 , 0 0 0}$ a year. 'The concessions agreed to were unimportant, and England, under the most favoured clause, shared the benefit. The Franco-Swiss tariff war lasted from 1891 to 1895 . The exchange of trade had averaged $£ 12,680,000$. It fell during the contest to $£ 9,390,000$. No advantage was gained on either side. With these experiences in view, we may agree with Lord George Hamilton that retaliation is a weapon to be used with caution, and only with the express authority of Parliament.

Benefits of com.

The discussion in which we are at the present time merce. engaged should carry our thoughts beyond the rivalries of trade and the circumstances of the hour. What is our ideal for the future? How best shall the material and moral welfare of our people and the national greatness be sustained? The powerful statesman who has set us all thinking has described in eloquent language the ideal he has in view. It is that of an Empire, self-centred, self-contained, politically, industrially, and commercially. All our supplies are to be drawn from our own dependencies, and in those dependencies chiefly we are to find a market for the products of British industry. This ideal is to be attained by means of preferential tariffs, very onerous to the people of this country, and without the hope of compensation by any reciprocal advantage.

The flow of trade may be compared to a mighty stream. How soon its waters become angry and troubled when any obstruction impedes their course! To the worker let the fullest liberty be given to sell his labour in the dearest, and to purchase his food and everything necessary in the cheapest market. The Government should give help where it can. It should never impede 
the movement of trade. To confine our commerce within the limits of the Empire would be a fatal policya policy in restraint of trade. The commerce of the British Empire should extend to every land. The wider its scope the more fruitful it will be of blessings, beyond the immediate getting of gain. ' Commerce,' it was once eloquently said by Lord Avebury, President Avebury. of the Chamber of Commerce of the United Kingdom, ' commerce is, after all, the great peacemaker of the world. As a peacemaker, commerce has done even more than religion. Differences of religion sometimes separate nations. Commerce is never militant. It binds us all together in links of gold, like marriage-rings.'

The objections to protection have been urged by none with greater force than by Mr. Chamberlain himMr. self. Speaking at Birmingham in 1885, he said: 'Do not suffer yourselves to be turned aside at the next election ; do not be diverted. The owners of property, those who are interested in the existing state of things, the men who have privileges to maintain, would be glad to entrap you from the right path by raising the cry of fair trade, under which they cover their demand for protection, and in connection with which they would tax the food of the people in order to raise the rents of the landlord. Protection very likely might, it probably would, have these results: It would increase the incomes of the owners of great estates; it would swell the profits of the capitalists who were fortunate enough to engage in the best protected industries; but it would lessen the total production of the country; it would diminish the rate of wages; and it would raise the prices of every necessary of life.'

Chamberlain. 


\section{CHAP'TER VIII}

SOCIAI, AND ECONOMIC CONDITIONS AT HOME AND

ABROAD : UNDER PROTECTION-UNDER FREE TRADE

Wages before repeal of corn laws.

WE have seen the development of trade as measured by the statistics. The condition of the worker shows steady improvement. Our country in former days was highly protectionist. Did trade flourish? Was the reward of labour liberal? The agricultural interest had long held a commanding influence in Parliament. With what result? No fewcr than five times, in the short interval between 1820 and 1837, Parliamentary inquiries were held on the subject of agricultural distress. It was shown that the farmer was crushed by exorbitant rents, while the labourer earned the miserable wage of $7 s$. to $8 s$. a week. In other trades these were the weekly wages: Shoemakers, $10 s$. ; miners, 18s.; ironworkers, $10 \mathrm{~s}$; ; carpenters, masons, $11 \mathrm{~s}$; t tailors, $11 \mathrm{~s}$. Corn was dear, and bread double the price of to-day. 'Nothing,' says Sir Spencer Walpole in his history of the period, 'could exceed the wretchedness which commenced in 1837 and continued to 1842.' 'The population of England and Wales was about 16,000,000. No fewer than $1,420,000$ persons were in receipt of relief. One in eleven was a pauper. The misery in the United Kingdom was intense. It was far exceeded by the misery in Ireland. The potato, the chief food of the 
people, had failed. The country was desolated by famine. In three years the population diminished by 650,000 souls. The condition of the country before free trade has been described by Mr. Chamberlain. Speaking at Ipswich on January 14, 1885, he said: 'The condition of the farmer was never so hopeless, and the state of the labourers was never so abject, as when corn was kept up at a high value by a prohibitive protective duty, when it was $64 s$. or even rose to $120 s$. per quarter.' Later in the same year, at Birmingham, he said: 'I wonder whether in this vast audience there are any people who have any conception of the state of things which existed forty or fifty years ago? At that time the whole of the labourers in the agricultural districts were on the verge of starvation. The poor-rates in some districts were $20 s$. in the pound. . . . At the time of which I am speaking, the large towns were described by eye-witnesses as bearing the appearance of beleaguered cities, so dreadful were the destitution and the misery which prevailed in them. People walked in the streets like gaunt shadows and not like human beings. There were bread riots in almost every town. 'There were rick-burnings on all the countrysides.'

The time at last came for a reconsideration of a fiscal system under which sufferings so cruel had been endured. 'Two orators of rare gifts arose to plead the cause of the people. 'The glowing rhetoric of John Bright, the convincing arguments of Cobden, carried constituency after constituency. 'The work they had begun out of doors was completed in Parliament, to his own enduring honour, by Sir Robert Peel. Rising superior to the trammels of party, and convinced of the necessity; that 
illustrious and wise statesman proposed and carried the repeal of the Corn Laws.

Progress under

We have the experience of nearly sixty years of free unee trade. trade. It has proved of immeasurable value to the
ind British working man of every class. His wages have increased. The cost of food has been constantly diminishing. With improving material conditions discontent has ceased. Populous London is hardly conscious of grievances remediable by legislation. 'The metropolitan representatives are by an overwhelming majority Conservative. The Liberal party has laboured in the cause of reform. The party which has opposed reform has profited.

Wages in England and Germany.

Our working people may with advantage compare their present earnings, not only with those of their own country in a past generation, but with those paid in Germany. Mean weekly wages in fifteen skilled trades : London, 42s. ; Berlin, 24s. Other towns-England, 36s.; Germany, 22s. 6d. a week. Staple industries-industries in most cases giving employment to several members of a family : Cotton trade, average annual family incomeUnited Kingdom, £115 17s.; Germany, £62 19s. Woollen trade-United Kingdom, £107 9s. ; Germany, $£ 57$ 10s. Steel trade-United Kingdom, £122 15s.; Germany, $£ 522 s$. The average level of industrial wages is for Germany two-thirds and for France threefourths of that prevailing in the United Kingdom. Of the 4,000,000 workers in Germany, two-thirds of the number earn less than $15 s$. per week; 65 per cent. less than $£ 40$ per annum; and 85 per cent. \&1 per week. 'Did these facts,' asked Mr. John Morley in his speech at Nottingham, 'show Germany 
to be a paradise? So far from being a paradise, it was not even purgatory, but a lower stage. All this was apart from the exhausting hours worked in Germany. Political discontent had greatly increased there since 1830, when food duties began to be imposed.' With one solitary exception, every representative of Berlin is a Socialist-as such, pledged to reverse the policy of exclusion and protection of privileged interests, cartels, and trusts, which is certain sooner or later to lead to misery.

As in wages, so in the hours of labour, the position of our working people is advantageous. Comparing Germany, France, the United States, and our own country, the hours are longest in Germany and shortest in the United Kingdom. The difference has been computed at twenty-nine days more in the year for the German than for the British worker.

Workers in Germany have no advantage in regularity of employment. The Franco-German War had a great effect in stimulating the trade of Germany. The increase Trade depression in Germany. in production and in exports was on a vast scale, but not on a sound basis. Production far outstripped the legitimate demand. A financial crisis followed. The economic condition of Germany after the war is thus described by the United States Labour Commissioner, Mr. Carroll : 'Five milliards of francs had been received from France. Money became too abundant. The field of industry was yielding enormous profits. The whole country swallowed the deceptive bait and entered vigorously into great industrial and financial undertakings. Manufacturers, instead of laying by their enormous profits, employed them to enlarge their facilities for 
production. Almost everybody was engaged in some sort of speculation. It is impossible to estimate the enormous sums lost through joint-stock enterprise.' In recent years Germany has once more been passing through a severe crisis. As the Commission on the Depression' of 'Trade observed, the tide of commerce ebbs and flows in all industrial countries. There is a constant tendency to increase the capacity for production, perhaps at a time when the demand is not sufficiently brisk to maintain remunerative prices and gire adequate return to capital. The depression due to over-production has been especially marked in the case of Germany.

The Report by Consul-General Schwabach on the trade of Germany for 1902 gives a gloomy picture. The depression in trade and industry experienced in Germany during 1901 continued to make itself felt, though in a less degree, during 1902. Industries unduly expanded with borrowed money were shut down everywhere. Want of employment and the lowering of wages crippled the purchasing-power of the mass of the population, and worked unfavourably. The managers of industrial undertakings, finding no home market for their output, forced the export trade to the utmost. It was in many cases unremunerative. The home iron industry was excessively dull. The electrical industry had not yet recovered from the blow received in 1900 and 1901 . The jute industry worked unsatisfactorily. All branches of the paper trade were depressed. The leather trade suffered from overproduction, and profits were small. In every centre of industry numbers were out of work. The ready-made 
clothing industry was at a standstill, the population of workers being too poor to buy. 'The year 1902 showed a depression and a diminution of profits even more marked than in 1901.

In his speech at the Queen's Hall meeting, Lord Goschen referred to the large numbers out of work in Gloyed in Germany at the present time. 'In Berlin and the district the metal workers amounted to about 72,000, of whom the greater part worked short time. Compared with October 1900 , from 18,000 to 19,000 fewer were employed. In Magdeburg, of 15,000 metal workers the larger number were on short time. Discharges were continually reported, and in January the number of unemployed amounted to 2,000. Town after town is represented in this way. In Barmen and Elberfeld 1,800 out of 4,000 work reduced hours. Altogether 400 to 500 were without employment.'

In its practical results cheap living is hardly less important than the scale of wages. Our working people Cost of living. under a free-trade policy have a conspicuous advantage. In the last quarter of the last century, the cost of living was reduced in the United Kingdom by 45 per cent., in Germany by 18 per cent. In the last five years a German workman has been able to purchase for 100 marks as much food of the kind to which he is accustomed as twenty years previously for 112 marks. The English workman has been able to make 100s. go as far in purchasing food as 140s. twenty years ago. The improvement in the relative position has becn continuous. In the ten years $1890-1900$ the price of food shows a fall of 6.9 points for the United Kingdom, as against one point for Germany. The food of the 
German workers consists of bread, potatoes, herrings, and coffee. The tax levied under the tariff on this meagre dietary is estimated at from $60 \mathrm{~s}$. to 70s. a year. In Germany the consumption of horseflesh as an article of food is increasing. It is not the food of a prosperous people.

Deficit in

Germsny.

The public finances of Germany are not flourishing. Baron Thielmann, in moving the Imperial estimates for 1903, spoke as follows: "The advance which characterised the last years of the past century has not only become slower, but a depression has taken its place, which has been accompanied by the collapse of important banking institutions and other undertakings. For 1902 the finances are about $£ 3,250,000$ short of the average increase. 'The estimates of 1902 close with a deficit of about $£ 1,750,000$.'

Russia. Let us turn to the economic conditions in Russia, as described by Bjoernsen, the Norwegian writer. The load of taxation has become intolerable. Expenditure is steadily increasing. Receipts can no longer keep pace with increasing charges. A part of the railway system is not paying working expenses. Taxation has reached its ultimate limit. The Government has been propped up by foreign loans. 'No centralised power, even the best, is for any length of time capable of governing so many and varied peoples. No hand, no matter how powerful, can stretch over such an enormous territory, presenting such variety of climate, and inhabited by populations with such marked racial and religious differences. But what the best government, what the most powerful hand, cannot perform, becomes chaos and misery under a feeble autocratic power, or 
a bureaucratic institution that is mercenary and mendacious, unstable and oppressive.'

With trade depressed and political aspirations unsatisfied, a general unrest prevails among the artisans of Russia. Socialistic ideas are diffused by ardent and fearless revolutionaries; strikes are incessant. Demands are pressed for higher wages, and even more for reduction of the weary hours of daily toil.

In the United States, protection has been from the beginning the settled policy. It has been associated United States. with sound principles on many subjects. It has stood for the honest payment of national debts, for free labour as against slave labour, for high wages for American labourers. In the United States protection has not given to the workers all the advantages which might have been expected. More than 29,000,000 persons are occupied for gain ; less than $1,000,000$ benefit by protection. Wages are high in the manufacturing industries, because all can find employment on the land. The rates, however, are declining, while the cost of living is continually increasing. 'The census returns of 1890 show that in thirty-three States there were $1,004,500$ wage-earners, receiving an average wage of 1.39 dollar a day. By 1900 the wage-earners had increased to $1,463,365$, while the wage had cieclined to 1.29 dollar a day - an average reduction of six per cent. In the same period the cost of living had risen six per cent., largely through the operations of trusts fostered by the tariff. The report of Mr. Bell, British Commercial Agent in the United States, describes the anxieties of the situation: 'Within the last five years living expenses have increased more in the United States than in the 
previous twenty years. 'These conditions, of course, cannot last, and can eventually only result in profound disturbance of social conditions. As long as the workmen continue to receive high wages, they do not inquire too closely into the reasons for the increased cost of the necessaries of life. When, however, the reaction comes, more will be heard of the questions of trusts and tariffs. Financial authorities in the meantime are advising caution on the part of commercial as well as financial interests. 'Though the country is still extraordinarily busy and prosperous, after five years of almost continuous growth the chances of reaction are much increased.'

Protection in the United States has not given regularity of employment to the workers, nor immunity to staple industries from over-production and the consequent fall in prices, profits, and quotations for securities in Wall Street. On the collapse of the Steel 'Trust the correspondent of the Economist reported as follows: "When the great Steel Company decided to shut down a number of its mills, the last straw was placed on the back of the business camel. Railways are buying fewer cars and less bridge-work. Building in New York, Chicago, and other cities is suspended because of labour troubles. In Colorado the entire State militia are in the field in an attempt to keep the peace between the Cripple Creek miners and their employers. A spirit of unrest prevails among the softcoal miners of Maryland. 'The great woollen-goods strike in Pennsylvania has proved a failure. Four thousand workers had to own themselves beaten, and the effect on the textile industry was far from happy. One-twelfth of the cotton spindles in the United States 
stand idle. There is a slackening of demand for retail goods all over the country.' We admire the energy, the enterprise, and the skill of the American people. Large profits have been realised and vast expansion has taken place. The benefits have not been fully shared by the mass of the people. The rate of increase of the population has considerably diminished.

Returning to our own country, all the indications point to an improvement in the condition of the people, sion on not indeed embracing all classes so fully as we might wish, yet comparing favourably with the progress in any other country in the New or the Old World. The report of the Commission on Labour, issued in 1894, which has been quoted in an earlier chapter (p. 13), bears testimony to the benefits we have reaped from the adoption of a system of free trade. 


\section{CHAP'TER IX}

IMPERIAL CO-OPERATION IN COIONIAL DEVELOPMENT

WE desire to advance the development of our Colonies. There are means less burdensome to ourselves and more helpful to our fellow subjects beyond the seas than taxation of food-supplies. Co-operation is possible between the Imperial and Colonial Governments in public works, in the construction of trunk lines of railway, in subsidies to steamships. Swift communication is a bond of empire. It was the policy of Sir Robert Peel to give aid to the Colonies by subsidies rather than by tariffs. The time seems opportune for suggestions.

Canadian mail service.
I. In Canada it is proposed to establish a fast mail service across the Pacific, connecting Vancouver with Australia. The subject was before the Congress of Commerce lately held at Montreal. In such an assembly attention was naturally directed mainly to the rapid conveyance of mails, and the facilities for trade. A former Secretary to the Admiralty may look to the possible advantages to the Navy. Vessels which can act as the eyes of the Fleet are necessary. We have lately built cruisers, equal in dimensions and cost to the most powerful battleships. 'The sea performances have in many instances left much to be desired. In the greyhounds of the Atlantic, carrying the mails at 20-knot speeds and over, in all weathers, breakdowns of 
machinery are rare. Practical instruction in engine-room and stokehold duties for newly entered men in the Royal Navy was formerly obtained in the transport service. It may be given, and with greater efficiency, by the establishment of a fast mail service to Canada, aided by a liberal subsidy from Imperial funds. The enginerooms should be manned from the Royal Navy. Such a service has been long desired in Canada. It would foster trade relations, and tend to unite the Empire.

II. It is in contemplation to make a new transcontinental railway north of the Canadian-Pacific. The undertaking is formidable for the Dominion. An Imperial guarantee on some portion of the capital required would be generous on the part of the Motherland. It would be a bond of unity. British commerce would share in the benefits from the opening up of a vast extent of fertile country.

III. We have recently experienced a shortage in the supply of cotton. Our resources might be largely Supply of cotton. increased if the native populations under our rule in West Africa and elsewhere received instruction in the cultivation and the preparation of the staple for the market. The question has lately been brought forward at the meeting of the Cotton Supply Association at Manchester. Prompt and vigorous action should be taken by the Government.

IV. A comprehensive scheme of water storage and irrigation has been recommended by Sir W. Willcocks irrigation. for South Africa, at an estimated cost of $£ 30,000,000$. The work must be long delayed unless the Mother-land can co-operate. 
Emigra. tion.

Court of Appeal.

Imperial Council of Defence.

V. New countries need population. Let us give State aid, where necessary, to emigration ; let us send of our best. South Africa offers a wide field for Stateaided settlement. It is hardly to be desired that these small islands should become in an ever-increasing sense the workshops of the world. They will lose their beauty and charm. Expansion in the Colonies is the true remedy for overcrowding at home.

VI. The Home-land and the Colonies may be more closely united by the establishment of an Imperial Court of Appeal. As Mr. Haldane has truly said, the administration of the supreme forms of justice by the best intelligences of the Empire would be for the common advantage of all the subjects of the British Crown.

VII. Impcrial federation is far off-perhaps unattainable. Meanwhile the conferences already held between the Secretary of State and the Premiers of the several Colonies have produced the happiest results. It may be possible to constitute a permanent Imperial Council similar to that proposed by the Committee of the Imperial Federation League, and including Ministers of Cabinet rank, representatives of the Colonies and India, and military and naval advisers. The Council would begin with Imperial defence.

Australian contribu. tions to

VIII. Let us relieve Australasia of contributions Navy. to the cost of the Navy. All such arrangements with self-governing Colonies are to be deprecated. They lead to debates which it is well to avoid. Local resources should be concentrated on local forces. They will be ready to help us in the hour of need. The 
opinions of the Ministers of past days were weighty on this point. Lord Grey and Sir Cornewall Lewis concurred in opposing such demands as are now being pressed in certain quarters. 'They held that the Colonies would have done their part if they relieved the Mother-country of responsibility for their local defence. The protection of the Colonies does not materially add to our expenditure. In framing Nary estimates, we look rather to the progress of other navies. Our shipbuilding programme depends on theirs.

IX. The salaries of Governors appointed by the Salaries of Crown slould be paid from Imperial funds. Causes of contention would be removed.

This enumeration is not exhaustive. Nor is it necessary to anticipate the many services which the Mother-country, in a generous temper of mind, may render from time to time in the development of the daughter-States. In this connection let us not speak lightly of the cricket field, Scores are watched with the same absorbing interest and with mutual admiration on both sides of the Equator. 


\section{CHAPTER $\mathrm{X}$}

NEGLECTED OPPORTUNITIES FOR TRADE:

NEW EMPLOYMENTS FOR THE LEAST CAPABLE

Neglect WE do well in the staple trades-in our textile and our humbler wares.

Montreal : dent of Manufacturers' Associa. tion. metallurgical industries. The genius of the British people is for serious and solid work. We excel where excellence of quality is demanded. With us the trend of trade is more and more to the supply of the world's demand for that which is of the best. We have neglected the humbler wares. Yet the humbler wares are needed. In the tropics, in India, even in our British self-governing Colonies, the affluent, whose demand is only for the best, are the few. Inferior wares, which we have regarded with contempt, find ready purchasers where the best qualities find no sale. At the Montreal Congress of the Chambers of Commerce of the Empire, wise counsel was addressed to British manufacturers by the late President of the Canadian Manufacturers' Association. While insisting on the retention of full protective duties for Canadian interests, $\mathrm{Mr}$. Ellis gave a long list of goods imported into Canada from the United States in lines in which no attempt is made by British manufacturers to compete. 'Last year,' he said, 'we had a balance of trade in our favour with Great Britain of 51,000,000 dollars. We had a balance of trade against us with the United 
States of $46,000,000$ dollars. In other words-of the $51,000,000$ dollars received from Great Britain, $46,000,000$ dollars were handed over to the United States in payment for goods which British manufacturers, had they been alive to their own interests, could have furnished. Great Britain supplies of watch movements $\$ 3,360$ out of a total import of $\$ 672,003$; of lamps and chandeliers $\$ 5,000$ out of a total import of $\$ 262,000$; of guns $\$ 24,000$ out of $\$ 250,000$; brass goods $\$ 89,000$ out of $\$ 500,000$. And yet these goods had to pay 50 per cent. more duty than the British goods have to pay.' These remarks deserve our careful consideration. There are other products of industrial skill in which we leave the field entirely to other nations. We import cheap pianos from Germany to the value of $£ 700,000$. Australia is also a large importer; yet British makers are scarcely known to Australian purchasers.

We may give more liberal grants in aid of technical education. Mr. Haldane has shown how urgent is the Technical education. need. It is galling to see any trade passing out of our hands which might remain with us if we were up to date in applied science. In the chemical trades, in electrical machinery and fittings, we have allowed business to slip through our fingers. We are recovering ground which should never have been lost. Let the State do all it can to help the workers and the captains of industry. We shall enter on a fatal course if we begin once more to lean on protection and a paternal government, in place of individual energy, enterprise, and skill. Our country has prospered, as no other country has prospered, in open competition. It has braced our energies. It has stimulated all our faculties. 
It has created that noble spirit of independence which has made our British race sturdy, vigorous, and manly, and our Empire a glory to ourselves and the wonder and admiration of the world.

Rural depopula. tion.

Proposals for putting a duty on corn commend themselves to some as a means of bringing population back to the land. They deplore the disproportionate growth of an urban population under poor physieal conditions. Such considerations appeal to all.

Ill fares the land to hastening ills a prey, Where wealth accumulates and men decay. Princes and lords may flourish or may fade, A breath can make them as a breath has made; But a bold peasantry, their country's pride, When once destroyed can never be supplied.

To effect the object in riew by fiscal changes, it will be necessary to put a heary charge on the poorest classes. Such a policy is impossible. By adopting the methods of cultivation still practised in Belgium and France larger numbers might be employed. Their earnings would be lower than under the modern system. With extended use of machinery two hands now produce as much as three hands fifty years ago.

In all countries there is a similar inerease in the urban as compared with the rural population. It is seen in France, where the numbers are almost stationary ; in the United States, where large tracts are still only partially settled; and in Germany, where the growing number of the dwellers in cities and towns, who must find in manufacturing industries the means of living, is a principal cause of the severe competition we have to meet. Let us endeavour to bring the people back to the land by better methods than the levying of duties 
on wheat. Let us build garden cities in pleasant places, where the workers in industries may live under clearer skies, and sometimes hear 'the live murmur of a summer's day.' These country joys, sung by the poet, are little shared by those whose lot it is to labour.

If our country is flourishing -if not only individuals, Employ. but large classes, are prosperous beyond the dreams of unskilled avarice-if even among the least fortunate there are workers. signs of progress-let us not rest content. And surely for the poorest, the submerged tenth, the millions with whom life is a hard struggle, some remedial measures are possible. We shall not improve their condition, nor help the traders and manufacturers of this country in the severe competition they have to face both at home and abroad, by returning to protection, which would make everything dearer, without increasing the reward of labour. Let us think of methods with more promise of yielding a good result.

For the unemployed, for those whose employment is least certain and least remunerated, the trouble is that they are unemployable. The tens of thousands whose condition has been described by Mr. Booth and Mr. Rowntree, or with distressful sympathy by the author of ' The People of the Abyss,' are incapable of earning a living in the staple industries. In the textile, in the metallurgical industries, in the building trade, even in the fields, they could not find employment. They have neither skill nor physical strength. How shall we put the submerged tenth-those that have gone under and are lying helpless-in the way of earning a livelihood ? The gloomy refuge of the workhouse, charitable doles in miserable homes, are a palliative, not a permanentremedy. 
'The aim should be to help people to help themselves. 'Teach the least capable some easy industry. They are not employable where highly skilled labour is necessary. There are some articles in extensive demand, and imported in ever increasing quantities, which the poorest and least efficient should be able, with some instruction, to produce.

Imports of Toys and Musical Instruments from Germany, 1902

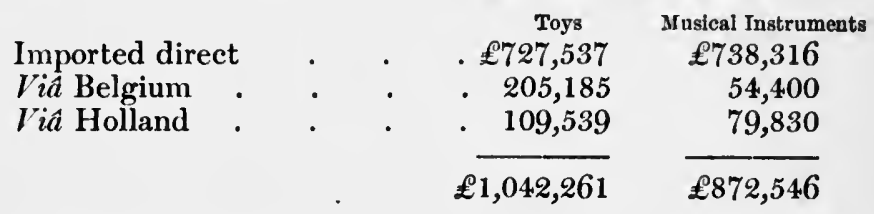

Goods of this humble description should be made at home.

Doctor. Barnardo.

As president of Dr. Barnardo's homes, I have seen what can be done by efforts unaided by the State to turn the most helpless into honest and capable workers, whether at home or in the far-off prairies of Canada. In the many institutions maintained under the administration of Dr. Barnardo the door is ever open to destitute children. They are admitted at all ages-even in infancy. They are allowed to remain until they are able to earn an honest living. The training for boys embraces many trades. The training for the girls fits them for domestic service. Taken by the hand at a tender age and kept under training and discipline in the days of their youth, the most miserable and degraded can be lifted up into sturdy and capable citizens. It is not going too far to say that Dr. Barnardo has worked with a success which has never been attained before in his particular line. 
Reform for those that have gone under is difficult in proportion to the advance of years. In the labour colonies in Australia-in the workshops established by General Booth-distress may be relieved by the State or by the philanthropist. The cases are rare where character is changed and the incapable are made efficient for any description of work.

It is not necessary to reproduce the wonderful statistics of Dr. Barnardo's work. The annual income, raised by voluntary subscriptions, and not from the wealthier classes, has gradually advanced from $£ 224$ to nearly $£ 200,000$ a year. Tens of thousands of children have passed through the homes. No less than 14,000 have been sent out to Canada. There has been scarce a failure. The majority are most successful. The sailing master of the Sunbeam, when in Australian waters, was a Barnardo boy. $\mathrm{He}$ was proud of it, and justly so. This truly noble and humane work, thus briefly described, should be taken in hand by the State on a national scale.

There is no reason for despair. If we hear more of poverty it is because we know more than did our forefathers of all that is going on around us. The numbers of our poor are not increasing. In the words of Lord Macaulay, 'the evils are with scarcely an exception old. That which is new is the intelligence which discerns, and the humanity which remedies them.' 


\section{CHAP'TER XI}

\section{REDUCTION OF WAR EXPENDITURE}

Trade would be promoted by economy in the public expenditure. Lord Rosebery, in a recent speech, insisted strongly on this urgent and long-neglected topic. ' Your public expenditure in $1883-84$ was $£ 86,000,000$ a year. Your expenditure in 1893-94, ten years afterwards, was $£ 92,000,000$; your expenditure in the current year (1903-04) is $£ 144,250,000$, or, putting in the expenditure which is put down to eapital, $£ 150,000,000$. In the last ten years the total ordinary expenditure of your Government has gone up about 62 per cent., whereas in the previous ten years it only went up 7 per cent.'

Increase of public debt.

In the last ten years we have raised the public debt to the total of $£ 798,349,000$; the charge for interest and repayment is $£ 27,000,000$ a year. Our debt is now as heavy as forty years ago. We see the result in the depreciation in Consols and gilt-edged securities. Our expenditure in 1903-04 on war preparations will be no less than $£ 68,957,000$, an increase of $£ 33,788,000$ on the expenditure of 1895 . Repeating the words of Lord George Hamilton, long at the head of the Admiralty, 'there are financial limits beyond which you cannot go without ruin to the Mother-land.'

Navy. Even in our administration of the Navy there is 
room for economy. It would be folly to disarm. We may cut down where we are spending wastefully. The growing expenditure on manning should be checked. The Admiralty has relied too much on permanent men. The vote for naval works has been for many years excessive. Payment having been made by loans, the vigilance of Parliament has been relaxed. The Naval Works Act of 1895 provided for an expenditure of $£ 8,800,000$. In the Act of 1901 the amount had increased to $£ 27,500,000$. Many works now in course of construction are necessary. Some are not necessary. The new works in Simon's Bay are estimated to cost $£ 3,500,000$. Capetown, the base for the mercantile marine, which we are bound at all costs to defend, is close at hand.

In this connection reference may fittingly be made to the recent cordial reception of the British Parliamentary delegation in France. It had its origin in the King's auspicious visit to Paris, followed by the visits of President Loubet and the French Parliamentary delegation to this country. The representatives of the British Parliament received an enthusiastic welcome. France sincerely desires an entente cordiale, and the cessation of a costly rivalry in naval preparations. In the happier phase in which we have entered, we see some prospect of relief for our burdened taxpayers. If other Powers are prepared to cut down expenditure, we are ready to follow.

After long delay, we have taken in hand the reform Army. of Army administration. The need is urgent. Avoiding details, a permanent force at home of $100,000 \mathrm{men}$, and a citizen army of 300,000 men, on the Swiss model. 
should be sufficient, if all were fit to take the field. Expenditure should be reduced. The Army votes before the war were under $\mathfrak{2 0 , 0 0 0 , 0 0 0}$. That amount should still suffice-if we keep down the numbers of the permanent men, relying for home defence on an efficient citizen army. 


\section{CHAPTER XII}

TRADE WITH TROPICAL COUNTRIES

In recent years we have suffered some loss of trade with protectionist countries. We have gained in the unprotected countries-chiefly within the tropics, in India, South Africa, China. The tables recently presented show the trend of our foreign trade.

Exports of Manufactured and Partly Manufactured Articles

\begin{tabular}{|c|c|c|c|c|}
\hline \multirow{2}{*}{ - } & \multicolumn{2}{|c|}{ Protected countries and Colonies } & \multirow{2}{*}{ All other countries } & \multirow{2}{*}{ Total } \\
\hline & Foreign countries & $\begin{array}{c}\text { Canada and } \\
\text { Victoria }\end{array}$ & & \\
\hline $\begin{array}{l}1850 \text {. } \\
1902:\end{array}$ & $\begin{array}{c}\text { Million } £ \\
34,842 \\
73,753\end{array}$ & $\begin{array}{c}\text { Million } £ \\
\mathbf{3}, 243 \\
13,309\end{array}$ & $\begin{array}{c}\text { Million } £ \\
28,715 \\
140,538\end{array}$ & $\begin{array}{c}\text { Million } \\
66,800 \\
227,600\end{array}$ \\
\hline Increase. & 38,911 & 10,066 & 111,823 & 160,800 \\
\hline
\end{tabular}

With all unprotected countries progress has gone forward for more than half a century without a check. Trade between the temperate zone and the tropics is, in the fullest sense, for the mutual advantage. The industrial populations of temperate countries are highly skilled, and capable of sustained effort. Supplies of fuel are abundant. 'The moist climate is favourable for textile industries. The tropics give, in exchange for manufactures, coffee, tea, cocoa, tropical fruits, fibres, india-rubber, and other raw materials. These products 
of fertile soils and a burning sun form each year a larger share of the importations into the temperate-zone countries.

By the expansion of trade in all our tropical possessions, and the free opening of our ports to the merchants of every country, Great Britain has rendered a service to the world. Travelling eastward, along the route of the Suez Canal, every port under the British flag, or under British protectorate, is a busy entrepôt of trade. Commerce is active at Gibraltar and Malta. What we have accomplished in Egypt has been recorded in Lord Cromer's annual reports and by Lord Milner. Aden-a huge and barren cinder on the sandy shore of Arabia-has attracted all the trade formerly centred in Mocha. Many hundred laden camels enter the gates every morning. Kurrachee has become the port of North-West India. Bombay, with its magnificent harbour, is at once the Manchester and Liverpool of the East. 'The capacious harbour of Colombo has been made secure by a noble breakwater. As a port of call it is one of the busiest in the world. At Calcutta we see the same combination as in Bombay of industrial activity and a vast movement of shipping. The jute factories of Calcutta are the creation of British enterprise and capital. For the trade of the further East I may refer to an American authority.

United States Bluebook.
The Blue-book relating to Colonial administration, lately compiled at Washington, deals specially with tropical Colonies. We are reminded that the Colonies of the world are chiefly located in the tropics, while the governing countries are in the temperate zone. Of the 140 Colonies, dependencies, and protectorates of the 
world, more than a hundred are in the tropics; and of the $500,000,000$ people governed by races other than that of the immediate territory which they occupy, fully 450,000,000 are in the tropics. Practically all the people within the tropics, except those on the American continent, are governed by temperate-zone nations. The more advanced Colonies, lying in the temperate zone, and peopled by natives of the Mother-country or their descendants, have already developed to a great extent their commerce and commercial relations with the world and with the Mother-country.' It is to the tropical Colonies chiefly that we should look for expansion.

The tropical imports into the United Kingdom considerably exceed $£ 60,000,000$. They include caoutBalance of trade. chouc, tea, jute, coffee and cocoa, fruits and oils, chemical drugs, dyes, and cabinet woods. The importation into the United States already exceeds our own large totals. The average value is over $£ 200,000$ a day. Our vast trade to the tropical countries is a prime factor in adjusting the balance of our indebtedness in the direct trade with the protected countries. The excess of our imports from France and the United States represents dividends on British investments, payments for freights, remittances to cover the expenses of European travel, and, to a large extent, importations of tropical produce supplied by British merchants, and exchanged by the producer against British manufactured goods. These operations of commerce have made London the chief centre of finance and trade. The amounts cleared at the London Bankers' Clearing House increased 
from $\mathfrak{E} 6,789,000,000$ in $1890-94$ to $£ 10,029,000,000$ in 1902.

India. The Anglo-Saxon genius for the development and administration of Colonies has found in India a wide field. In 1901, 25,373 miles of railway had been constructed, the capital having been raised with the aid of the State. No less than 30,000,000 acres of land have been made fertile by irrigation. Jute-mills, cotton-mills, and many other flourishing industries have been established by British capital and enterprise in every part of India. The external trade of India has expanded with the growing prosperity and power of production, and the lion's share has fallen to the United Kingdom. It has been well, not only for the prosperity of the United Kingdom, but for the general trade of the world, that India has not been in the hands of a protectionist Power. The ports would have been closed to every foreign flag. The revenue of India exceeds $£ 100,000,000$. Not more than five per cent. is contributed from Customs. Busy ports, such as Hong Kong and Singapore, are free. The policy of Great Britain is not exclusive.

Java. Java offers another example of the results which may be achieved in the development of a tropical country under European administration. The exports of Java in 1870 amounted to $61,000,000$ guilders. In 1898 they had risen to $203,000,000$ guilders-an increase of 230 per cent. In 1870 the imports of merchandise amounted to $44,000,000$, and in 1898 to $160,000,000$ guilders-an increase of 250 per cent.

Hong

Kong and The value to commerce of the establishment of disSingapore. tributing centres is seen conspicuously in the trade of 
Hong Kong and Singapore. Hong Kong was ceded to Great Britain in 1841, and the Straits Settlements in 1824 in exchange for Sumatra. Hong Kong has become a distributing centre for British goods in transit to China, Japan, and the Philippines ; Singapore has become the centre for Siam, Burma, Indo-China, the Malayan Peninsula, and the East Indian Islands. The trade from these central points of distribution is described in the American Blue-book: "The value of the markets of the great semicircle of countries and islands to which Hongkong, Singapore, and Manila may form convenient distributing points is more than a billion dollars annually, or, to be more nearly exact, about $1,200,000,000$ dollars annually, an average of $200,000,000$ dollars per month. The annual importations of Japan, Korea, Asiatic Russia, China, Indo-China, Siam, the Malayan Peninsula, India, the East Indian Islands, and Australia, which aggregate the enormous sum above named, are chiefly of the classes produced only in the temperate zone. Breadstuffs, provisions, and manufactures of all kinds form the large bulk of this great importation, and it is in these articles, especially manufactures, that the United Kingdom has built up her commerce with the countries adjacent to her great distributing centres in the Orient from $£ 2,000,000$ in 1840 to twelve times that sum in 1900.'

The South African Colonies give promise of a rapid development. Trade was disorganised during the war. South Since the return of peace the value of British exports to the South African Colonies is inferior only to the trade with India. 'The present rate of expansion can be maintained. South Africa may become the first among 
British possessions as a market for the products of the Mother-country.

Britisi Produce to South Africa

\begin{tabular}{|c|c|c|c|c|c|}
\hline- & - & India & United States & Germany & Australia \\
\hline $\begin{array}{l}1900 \\
1901 \\
1902\end{array}$ & $\begin{array}{c}£ \mathrm{~ms} . \\
13 \cdot 5 \\
17 \cdot 8 \\
25 \cdot 7\end{array}$ & $\begin{array}{c}£ \mathrm{~ms} . \\
\overline{32 \cdot 3} \\
30 \cdot 1\end{array}$ & 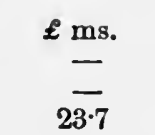 & $\begin{array}{c}£ \text { ms. } \\
\overline{22 \cdot 8}\end{array}$ & $\begin{array}{c}f \mathrm{~ms} . \\
\overline{21 \cdot 3} \\
19.5\end{array}$ \\
\hline
\end{tabular}

Expansion of trade with tropics.

In seeking new outlets for our trade with our own possessions, we should look not only to the self-governing Colonies, where we compete with protected local industries, certain to become in time as efficient as our own, but rather to those vast regions of the globe where the conditions are not favourable to manufacturing industries, and where the combined advantages of skilled labour and untaxed food and raw materials have enabled our manufacturers to hold thus far a commanding position. The observations in a preceding chapter on the policy of Imperial subsidies in aid of Colonial development apply in a special sense to those tropical possessions where the local resources are necessarily inadequate in an early stage. 


\section{CHAPTER XIII}

\section{CONCLUSIONS}

IN concluding an imperfect examination of our trade $\mathbf{M r}$. position and the proposed change in our fiscal policy, it lain. is obvious, in the first place, that a question of the highest importance has been raised with great suddenness. The prosperity of the country, the unlooked-for manifestation of loyalty on the part of the Colonies in sending their contingents to South Africa, had given to the world the proof of the unlooked-for elasticity of our imperial resources. And now, with no previous word of warning, Mr. Chamberlain has sounded the note of alarm at the prospects of trade. At home he sees the markets invaded by goods dumped down by the foreigner, liberally subsidised, and thus enabled to sell his productions abroad at prices below their cost. He sees the doors, once open, now closing against us everywhere.

And there are the political considerations. This noble Empire, this proud and splendid heritage from our Policy of retalia. forefathers-all this is crumbling to decay. Disruption is imminent. What are the remedies for these evils? Against foreign competitors we are to wage a war of tariffs. They bar us out. Shall we lie down and be trampled on? No. We will rise up. We will expel the foreigner from the land. We will trade only with our brethren-our brethren across the sea. They are 
few to-day. They will multiply under the stimulus of prosperity, great already - to be made greater still by preferential tariffs. They will supply all our food. They will take all our manufactures. Their allegiance, now wavering, will be restored by giving them the monopoly of our markets.

Suppor-

In Lord Rosebery's opening words at Sheffield, ters of protection. ' what do you think of it?' We know what many think of it. They are spellbound by the magic of skilful advocacy. There is no advocate more skilled than Mr. Chamberlain. $\mathrm{He}$ is the more persuasive for others because so fully persuaded in his own mind. Like the advocate in a court of law, he sees only one thing at a time. He knows his own point of view. He has a policy and a plan. He is sure that he is right - sure of his arguments. He does not 'greatly care for facts.' We must not forget that Mr. Chamberlain has long been Secretary of State for the Colonies. As he himself told us, when meditating on things on the lonely veldt, Colonial interests seemed everything and the interests of the United Kingdom scarcely more than parochial. Concentration on his own department has warped his judgment.

The new movement is helped forward not only by the magnetic personality of the leader, but by the combination of many influences. Among the industrials and the merehants, how few are as prosperous as they would wish! Many think they would do better if the foreigner were out of the way. There are those interested in the land, who sigh for a return to protection. Rents have declined. It is hoped that they would increase with higher prices for 
produce. And then there are the workers. They are the many, and the many govern. Speakers on both sides appeal to the workers. They dwell on the numbers of the unemployed who would be in employment if foreign goods were kept out of our home markets. From the other side the workers hear of the cruel burden of taxes on food, with no possible compensation in higher wages or more work to do. How few of those who most enthusiastically applaud Mr. Chamberlain's oratory and read his persuasive speeches have examined, or could examine and collate, the facts for themselves! The reports of long speeches are repugnant. How much more repugnant are hundreds of pages of statistics! Never has a question been before the public of which it would be more true to say, using the words of Mr. Burke, 'there are but very few who are capable of comparing and digesting what passes before their eyes at different times and occasions, so as to be able to form the whole into a distinct system.'

During my residence in Australia I mixed with all classes; I visited every State within the Commonwealth. I never heard a word of disruption. I was there when, in obedience to a popular sentiment, deeply and universally felt, the resolve was taken to send contingents to Australian South Africa. There was no obligation. The people loyalty. were moved by racial sympathy, by love for the old land, by loyalty, and by patriotism. They did not think of tariffs. They felt as deeply in the protectionist city of Melbourne as in the free-trade city of Sydney.

I have recently visited Canada. At the Congress of Canada. Chambers of Commerce of the Empire, the sentiment 
was intensely loyal. We sang 'God save the King' four times a day, as only our Colonial fellow-subjects can sing it.

Our

Colonial policy generous.

Why, indeed, should our self-governing Colonies desire to sever their imperial ties? We treat them with generous confidence. We import all their products dutyfree, and ours is their best market. We give unlimited powers of self-government, and all the privileges of British citizenship. We stand ready to shed the last drop of blood in their defence. Such being the terms-the generous terms-on which the unity of the Empire is maintained, it can hardly be claimed that we, in this old land, burdened with manifold responsibilities, should lay upon ourselves taxes on food and taxes on raw materials, unless some effective reciprocal advantages are offered. It is for Canada, for Australia-practically no other of our vast British possessions is in question-to say whether they are ready for free trade. Their industries are in an early stage of development, and need protection. The preference we have thus far received is not an effective preference. If we ourselves are barred out by a tariff sufficiently protective to exclude our goods, a still more prohibitory tariff against foreign countries does not help us. We have as yet no indication of a change in Colonial fiscal policy. In Australia the labour party is the ruling force. Its representatives favour protection and bounties to local industries. Canada has been even more protectionist than Australia. In trade with Canada the United States have a geographical advantage over the United Kingdom, not only for the supply of those raw materials which we cannot produce, but for the supply of manufactured articles to meet colonial 
requirements. In every dependency of the Empire, except in Canada, the United Kingdom has, under existing conditions, the lion's share of their import trade in all articles which we are able to produce.

As between the Mother-country, which desires to increase her exports, and a Colony which desires to of fiscal protect young industries in the home market, any bargain must be difficult. The representatives of the Canadian industries at the Montreal Congress did not conceal their views. Their spokesman was Mr. Ellis, a former President of the Canadian Manufacturers' Association. He said: 'I want to be perfectly frank. I do not think anything is to be gained by hiding back the situation which we accept; and I wish to say that, as far as Canadian manufacturers are concerned, we believe we have gone far enough. We will oppose strenuously any reduction in the present duties.' While the self-governing Colonies continue protectionist, a fiscal union is impossible.

The new fiscal policy is advocated as a bond of Imperial unity. A preferential tariff on conditions very onerous to the Mother-country, and not conferring any sensible advantage on the Colonies, is a feeble link in comparison with the ties of racial sympathy. If these were weak, it were vain to look for a rally round the old flag in the hour of national peril. The true links of Empire are the racial sympathies-the language and literature, the history which we all share, the constitution under which we all live, the religion we all profess. The bonds of such a union are silken bonds; but they are strong as adamant, and they give a powerful moral support to the Mother-land. 
Let us do what in us lies to promote the material progress and prosperity of the Colonies. There are more effective and less burdensome expedients than the laying of duties on food and raw materials. Let us be liberal-more liberal than heretofore-in subsidies to well-considered projects for all Imperial objects.

Retaliation and statistics of pro. gress.

The arguments for retaliation are plausible. They are less conclusive on closer examination. Let us once more pass in review the leading facts and figures in the Blue-book lately issued.

\section{Exports of Manufactured Goods}

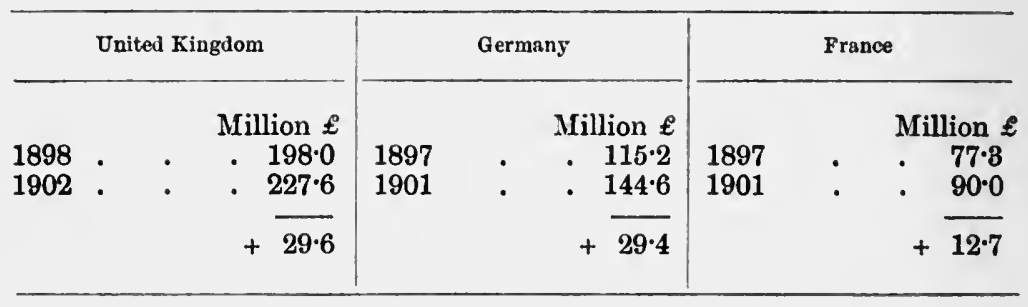

Exports per Head of Population

\begin{tabular}{|c|c|c|c|c|c|}
\hline \multicolumn{2}{|c|}{ United Kingdom } & \multicolumn{2}{|c|}{ Germany } & \multicolumn{2}{|c|}{ France } \\
\hline $\begin{array}{l}1898 \\
1902\end{array}$ & 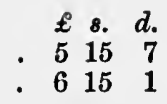 & $\begin{array}{l}1890-94 \\
1895-99\end{array}$ & 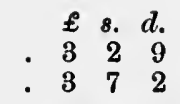 & $\begin{array}{l}1890-94 \\
1895-99\end{array}$ & 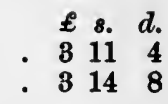 \\
\hline \multicolumn{2}{|c|}{ Population, $41,000,000$} & \multicolumn{2}{|c|}{ Population, $56,000,000$} & \multicolumn{2}{|c|}{ Population, $38,514,000$} \\
\hline
\end{tabular}

British Trade to Foreign Countries and British Possessions

\begin{tabular}{|c|c|c|c|c|}
\hline & & & Foreign Countries & British Possessions \\
\hline $\begin{array}{l}1880-84 \\
1895-99\end{array}$ & : & . $\quad$ • & $\begin{array}{c}\text { per cent. } \\
65.5 \\
66.0\end{array}$ & $\begin{array}{c}\text { per cent. } \\
34 \cdot 5 \\
34\end{array}$ \\
\hline
\end{tabular}


The table below is from the Board of Trade memorandum of 1902.

Imports into Neutral Markets from the United Kingdom, Germany, France, and the United States, respectively. Average for 1898-1900

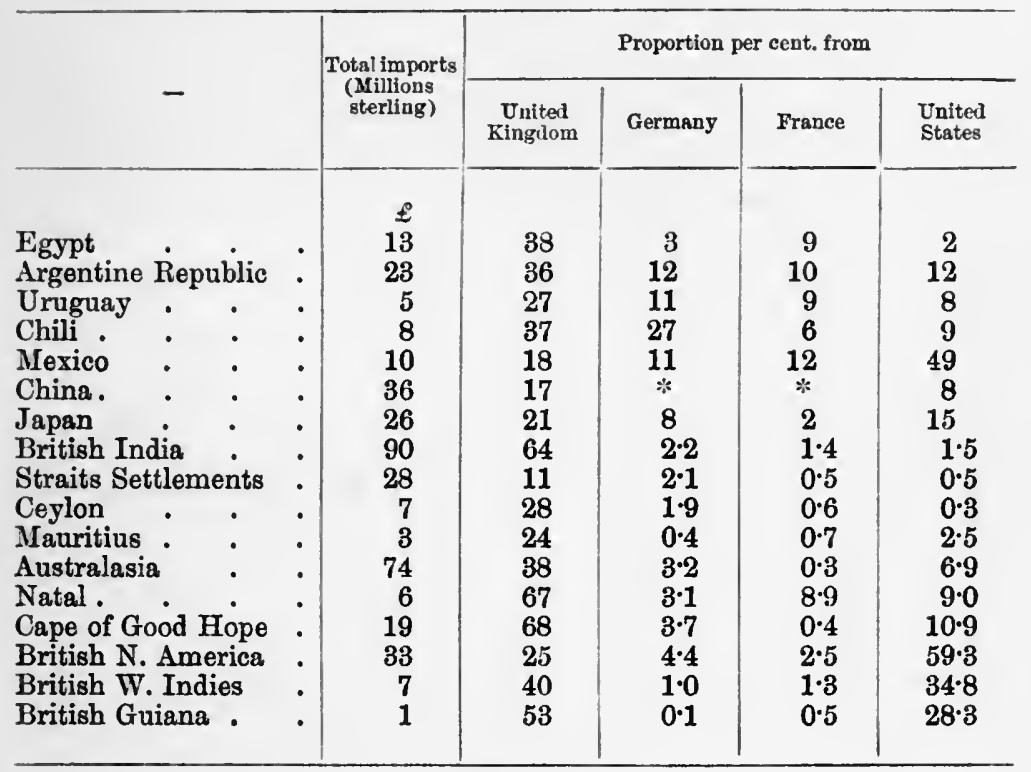

- Not distinguished.

\section{General Statistics of Progress}

Gross value of Property assessed to Income Tax :

$$
\begin{array}{ccccc}
\text { Average } 1890-94 & \ldots & \ldots & \ldots & £ 703,000,000 \\
1902 & \ldots & \ldots & \ldots & £ 902,000,000
\end{array}
$$

Deposits in Post-Office Savings Banks :

$$
\begin{array}{ccccc}
\text { Average } 1895-99 & \ldots & \ldots & \ldots & £ 163,000,000 \\
1902 & \ldots & \ldots & \ldots & £ 197,000,000
\end{array}
$$

Depositors in Post-Office Savings Banks :

$$
\begin{array}{ccccr}
\text { Average } 1895-99 & \ldots & \ldots & \ldots & 8,787,000 \\
1902 & \ldots & \ldots & \ldots & 10,803,000
\end{array}
$$


Our country has greatly prospered. It is for the advocates of change to give proof of its necessity. Under protection we shall lose all the advantages of a free-trade country in competition with hampered and hindered industries. Let us pause before we reverse the policy of fifty prosperous years.

Weight of authority.

Economists and statesmen are by a strong majority in favour of free trade. The Liberal party is united on the fiscal question, and it is strongly reinforced from the other side. The Cabinet was divided, and the Prime Minister found it difficult to fill vacancies. 'The leaders of the Unionist party have mustered in their strength under the Duke of Devonshire, still ready to obey the call of duty after long years of service in the highest offices of State. And who were they who were seen in imposing array at the memorable meeting in the Queen's Hall ? They were able members of the Conservative Ministry_Lord James of Hereford, Lord George Hamilton, Sir Michael Hicks-Beach, Mr. Ritchie, Lord Balfour of Burleigh, and, among the younger men, Mr. Arthur Elliot, Secretary to the 'Treasury, Mr. Winston Churchill, and Lord Hugh Cecil. Those specially called upon to consider fiscal questions have been unanimous-three Viceroys of India-the Earl of Northbrook, the Earl of Elgin, and the Marquis of Ripon ; four Chancellors of the Exchequer-Lord Goschen, Sir Michael Hicks-Beach, Sir William Harcourt, and Mr. Ritchie. In all our long Parliamentary history, never has the weight of authority on any issue been so commanding as to-day in favour of free trade.

Demands for protection are insatiable. The clamour 
becomes more urgent with every concession. Convinced free-traders should be up and doing. 'Omne malum nascens facile opprimitur: inveteratum fit robustius.'

If unjustly treated by any nation, we shall be in full accord with free-trade principles in looking to our own interests, and adopting such measures as may from time to time seem best. 'To return to protection would be disastrous. 


\section{CHAPTER XIV}

\section{INQUIRY BY ROYAI COMNISSION}

Whes proposals are made by a powerful Minister in the responsible position of Secretary of State for the Colonies, having for their aim an object which we all approve, they claim attention. Let us not say that inquiry is unnecessary. We may insist that it should be thorough and impartial. Some weighty words once used by Lord Salisbury should be remembered at the present juncture. In his reply to a deputation from the Imperial Federation League, in 1891, he spoke as follows: "The solution of this problem does not lie on the face of it. It will require the labour of many able minds before a satisfactory solution is arrived at. To make a united empire, such as you have in Germany, and such as, in the largest sense of the word, you have in the United States-to make that out of the scattered elements of the Queen's Empire, you have two difficulties : you have to found a union for war and a union with respect to Customs policy. Your difficulties with respect to a Customs policy you know. A Kriegsverein means some control of foreign policy. It means a balance or appraisement of the voting value of the different elements of which the empire is composed. The matter is not one for vague sentiment; it is one for hard thinking and the utmost effort that the strongest intellect of our time can give.' 
And now, how shall we end a controversy of which we are growing weary? If Mr. Chamberlain prevails, what will he do? He has said, 'Give me a mandate, and I will negotiate.' He would go to the Colonies and say, 'I am ready to propose to the British Parliament a fiscal policy for your advantage. Can you reciprocate?' If he heard in reply all that was urged by the Canadian delegates last year at the Colonial Conference; if he heard the speeches delivered at the Montreal Congress by Sir Wilfrid Laurier and his colleagues-well, we know what Mr. Chamberlain would say. He would say: 'I am disappointed. I was willing to make very generous proposals on your behalf. They would have entailed to the people of the Mother-land a heavy sacrifice for your benefit. I cannot make such proposals, unless for the mutual advantage.' Preferential tariffs, of which we have been hearing so much of late, would drop out, as the scheme once so eloquently propounded for universal pensions to the aged poor has dropped out, from the programme of the Government.

It would be the same with the policy of retaliation. Mr. Chamberlain, in a position of responsibility, would doubtless endeavour to deal cautiously with a policy of retaliation. As the leader in a new movement, he is appealing with unrivalled art for popular support. $\mathrm{He}$ appeals not only to the reason but to the prejudices of his audience. Mr. Chamberlain has said what he would do if he received a mandate from the country. He would call together a committee of experts in every branch of trade; he would ascertain their views. When we descend from vague denunciations of foreign commerce to a practical scheme-to a specification of the goods to 
be taxed, and a schedule of duties-it will be as the casting of the apple of discord into the garden of the Hesperides. The producers of commodities which will be raised in price will receive a boon, perhaps in silent gratitude. Every consumer will remonstrate; and the consumers are the many. As with preferential tariffs, so with retaliation for the benefit of our home industries-it will be found in the end that little can be done.

Meanwhile, Mr. Chamberlain has called to his assistance a committee in sympathy with his own views. A scheme will be formulated. The new policy will be presented in a concrete form. An examination by a representative and responsible body must follow. It is impossible for the constituenciesnay, impossible for Parliament-fully to investigate the facts and their bearing on fiscal policy. A Royal Commission is best fitted for the task.

The issues which Mr. Chamberlain has raised are of momentous import. They should be examined by capable and impartial men. The able officials in high posts in the public service should be consulted. Their advice is the more valuable because they have the knowledge of experts and are disinterested. Guided by such advice the British people, with unfailing common sense, will come to a wise decision. 'They will find other and better means than the obstruction of trade for maintaining the noblest Empire which the world has seen. 


\title{
APPENDIX
}

\author{
Reprinted from the 'Free Trader'
}

\section{BRITISH AND FOREIGN TRADE IN 1903}

THE monthly Accounts relating to Trade and Navigation for December last, just issued by the Board of Trade, contain a summary of the figures for the whole year 1903, in comparison with the two preceding years. The figures give no kind of support whatever to those who are proclaiming the evil state on which British industries have fallen. In every respect 1903 has been a record year. We set out first the figures of imports and exports for the last three years :-

\begin{tabular}{ccc} 
Year & $\begin{array}{c}\text { Imports c.i.f. } \\
\text { (including bullion and specie.) }\end{array}$ & Exports f.o.b. \\
1901 & \multirow{E}{f}{} & $\mathfrak{E}$ \\
1902 & $521,990,198$ & $347,864,268$ \\
1903 & $528,391,274$ & $349,238,779$ \\
& $542,906,325$ & $360,457,316$
\end{tabular}

The total of the year's trade is then over $£ 903,000,000$, or $£ 25,000,000$ more than any previous year.

As compared with the preceding years, imports show an increase of $£ 14,500,000$ over 1902 and $£ 20,000,000$ over 1901 . When these increases are examined in detail they are found to be almost entirely in food and raw materials. The increase in imports of 1903 over those of the previous year is made up as follows :-

Food, drink, and tobacco ... $\quad \ldots \quad \ldots \quad \ldots \quad £ 8,102,099$

Raw materials and articles mainly unmanufactured $\mathfrak{\ell , 5 1 2 , 2 4 0}$

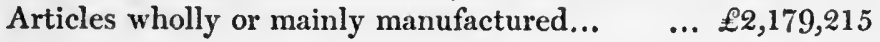

(The group called miscellaneous has declined to £278,503.)

In regard to the first group, it is noteworthy that tobacco has

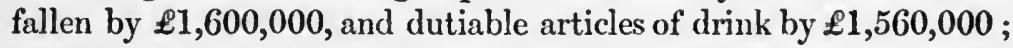
whilst grain and flour have risen by $£ 3,750,000$; meat, including articles intended for food, by $£ 2,500,000$; and non-dutiable articles 
of drink by $£ 2,175,000$. Last year we imported articles of food and drink to the value in all of $£ 228,000,000$.

'The total outlay upon meat, both live and dead; was

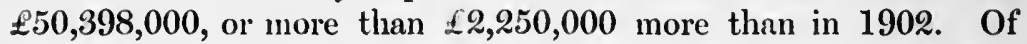
fresh beef more than two-thirds came from the United States, and nearly all the remaining one-third from Argentina. Of fresh mutton rather more than one-half came from New Zealand and one-third from Argentina. Of bacon, the total import last year was $£ 13,600,000$. It is interesting to notice that $£ 7,370,000$ worth came from the United States, $£ 4,294,000$ from Denmark, and $£ 1,691,000$ from Canada. We spent $£ 1,500,000$ upon fresh pork, chiefly from Holland, the United States, and Belgium ; $£ 245,000$ on salted beef, mostly from the United States ; $\$ 319,000$ on salt pork, also chiefly from the United States; and £724,000 upon rabbits, chiefly from Australasia and Belgium.

Eggs established a record. They rose to $£ 6,617,000$, or $£ 1,000,000$ in excess of the figure of 1901. It is curious that the largest source of supply is Russia (which sent $£ 1,866,000$ worth), followed closely by Denmark. Our imports of butter also reached the maximum hitherto attained, being only a little less than $£ 21,000,000$ in value. Nearly half of this, or $£ 9,500,000$,

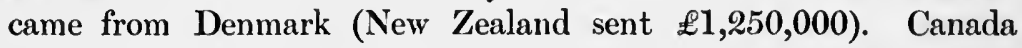
heads the list in the supply of cheese with $\mathscr{E} 4,820,000$ out of $£ 7,054,000$.

'The wheat supply from abroad continues to increase. Last year's amount rose from $81,000,000 \mathrm{cwt}$. in 1902 to $88,000,000$ cwt., and the value increased from $£ 2 \%, 000,000$ to nearly $£ 30,000,000$ sterling. The supply from the United States declined somewhat; it was $24,000,000$ cwt., as against $43,000,000 \mathrm{cwt}$. in the preceding year. On the other hand, the supplies from Russia were more than double, and rose from $6,540,000$ cwt. to over $17,000,000$ cwt., and the quantities received from Argentina increased from 4,000,000 to 14,000,000 cwt. The British East Indies also came to the rescue, and sent us over 17,000,000 ewt., as against 9,000,000 cwt. in the previous twelve months. Canada, on the other hand, only increased from $9,500,000$ to $10,800,000$. In the case of flour $£ 7,500,000$ worth out of $£ 9,750,000$ came from the United States. The wheat figures illustrate the extreme importance of doing nothing what- 
ever which would tend in any way to limit the area of supply on which we can draw, in the event of a diminution of the quantities obtainable from any one particular country.

In the second group of imports of articles, mainly unmanufactured, the increase was chiefly in cotton, which rose by $\$ 3,750,000$, and wool and timber, which rose by nearly $£ 2,000,000$. Wool advanced $£ 600,000$, and metallic ores, not iron, $£ 500,000$, and the miscellaneous class $£ 843,000$. On the other hand, there was a fall in iron ore, in oil, seeds and nuts, and in hides and skins, and a very large fall (of $£ 1,500,000$ ) in the group made up of such textile materials as flax, hemp, jute, and silk.

In the third group articles wholly or mainly manufactured, iron and steel and the manufactures thereof, increased $£ 750,000$. Cotton yarns and textiles increased $£ 1,368,000$, and miscellaneous $£ 1,500,000$. On the other hand, there was a fall in cutlery and hardware, in machinery, in chemicals, and in metals and manufactures not of iron and steel. A word of warning is necessary to those who use only the summary tables. They appear to show an enormous increase of nearly $£ 3,000,000$ in the import of apparel. But a reference to the subsequent detailed tables shows that this large increase is only apparent, and is the result of a new classification made for the first time only in 1903 .

When we turn to the export tables it is necessary first to distinguish between the two groups of exports, the British and Irish produce and the foreign and Colonial produce. We give the figures for the last three years :-

\begin{tabular}{|c|c|c|}
\hline Year & $\begin{array}{l}\text { British and Irish } \\
\text { exports } \\
£\end{array}$ & $\begin{array}{c}\text { Foreign and Colonial } \\
\text { exports } \\
\underbrace{2}\end{array}$ \\
\hline 1901 & $280,022,376$ & $67,841,892$ \\
\hline 1902 & $283,423,966$ & $65,814,813$ \\
\hline 1903 & $290,890,281$ & $69,557,035$ \\
\hline
\end{tabular}

So that between 1901 and 1903 British exports increased $£ 10,868,000$. Mr. Balfour objects to including machinery and new ships in our exports. If we take these out, in 1901 and 1903, the result is still more favourable, for our other exports have increased $£ 13,500,000$. Of the increase between 1902 and 1903 in the exports of British and Irish produce of $£ 7,466,315$, practically the whole is in articles entirely or mainly manufactured. The export of articles of food, drink, and tobacco has 
decreased $£ 750,000$; and the export of raw materials and articles mainly unmanufactured has increased by rather more than a corresponding amount. But the export of manufactured goods has risen by $£ 7,354,420$, and it is remarkable that this improvement is not confined to one particular branch of industry. All the sixteen groups into which the Board of 'Trade divides our' exports of manufactured goods show an increase with one exception, and that exception is telegraphic cables and apparatus-an industry whose exports are sure to fluctuate very considerably from time to time.

We give below the figures for a number of industries :-

$$
\text { Iron and Steel Manufactures }
$$

$\begin{array}{ccccc}1901 & \ldots & \ldots & \ldots & £ 25 \cdot 0 \text { millio } \\ 1902 & \ldots & \ldots & \ldots & 28 \cdot 8 \quad, \\ 1903 & \ldots & \ldots & \ldots & 30 \cdot 4\end{array}$

(These figures are remarkable in view of the great difficulties which the cotton industry has encountered in the past year, owing to the shortage of raw material.)

Glass Manufactures

\begin{tabular}{rrrrr}
1901 & $\ldots$ & $\ldots$ & $\ldots$ & $£ 1,051,000$ \\
1902 & $\ldots$ & $\ldots$ & $\ldots$ & $1,098,000$ \\
1903 & $\ldots$ & $\ldots$ & $\ldots$ & $1,102,000$ \\
& \multicolumn{4}{c}{ Chemicals } \\
1901 & $\ldots$ & $\ldots$ & $\ldots$ & $£ 10,963,000$ \\
1902 & $\ldots$ & $\ldots$ & $\ldots$ & $11,559,000$ \\
1903 & $\ldots$ & $\ldots$ & $\ldots$ & $12,079,000$
\end{tabular}




\section{Refined Sugar and Candy}

$$
\begin{array}{rrrrr}
1901 & \ldots & \ldots & \ldots & £ 350,000 \\
1902 & \ldots & \ldots & \ldots & 399,000 \\
1903 & \ldots & \ldots & \ldots & 615,000
\end{array}
$$

So much has been said about the decline of the woollen industry that the figures deserve.careful attention. The exports were $£ 21,691,000$ in $1901 ; £ 23,308,000$ in $1902 ; £ 25,387,000$ in 1903, and this progress is not due to the increase in the price of raw material. The advance in the exports has been both in value and in quantity. The following are the figures for manufactured goods :-

\begin{tabular}{lrrrrr} 
& & 1901 & \multicolumn{1}{c}{1902} & \multicolumn{1}{c}{1903} \\
Woollen tissues in million yards & $\ldots$ & $44 \cdot 8$ & $47 \cdot 1$ & $50 \cdot 7$ \\
Worsted tissues in million yards & $\ldots$ & $93 \cdot 9$ & $102 \cdot 6$ & $106 \cdot 4$ \\
Carpets in million yards & $\ldots$ & $\ldots$ & $7 \cdot 5$ & $7 \cdot 6$ & $8 \cdot 7$ \\
Blankets in thousand pairs & $\ldots$ & $\ldots$ & 779 & 785 & 790 \\
Plushes, wool, and moliair, in 1,000 & yds. & $94 \cdot 5$ & $62 \cdot 8$ & $115 \cdot 9$ \\
Flannel in million yards & $\ldots$ & $\ldots$ & $9 \cdot 7$ & $8 \cdot 5$ & $8 \cdot 7$ \\
Woollen yarns in million yards & $\ldots$ & 11 & $1 \cdot 3$ & $2 \cdot 0$ \\
Worsted yarn in million lbs. ... & $\ldots$ & $47 \cdot 3$ & $51 \cdot 4$ & $57 \cdot 8$
\end{tabular}

In woollen manufactures there is a marked increase to the United States, and this in spite of the tariffs. The export of woollen tissue to that country has advanced from 1.4 million yards in 1901 to 1.8 million yards in 1903; worsted tissues from $21,000,000$ yards in 1901 to $26,000,000$ yards in 1903 ; and carpets from 198,000 yards in 1901 to 352,000 yards last year.

We have never agreed with those people who regard export trade as the sole test of a nation's industrial prosperity. In the statistics of British trade of last year there is no evidence of any kind of decay. But, on the other hand, there is abundant evidence that we are maintaining and improving our position in spite of all the difficulties with which we are surrounded, and it is perfectly clear that we are quite capable of facing and overcoming these difficulties so long as we are not hampered. 

.

\section{.}






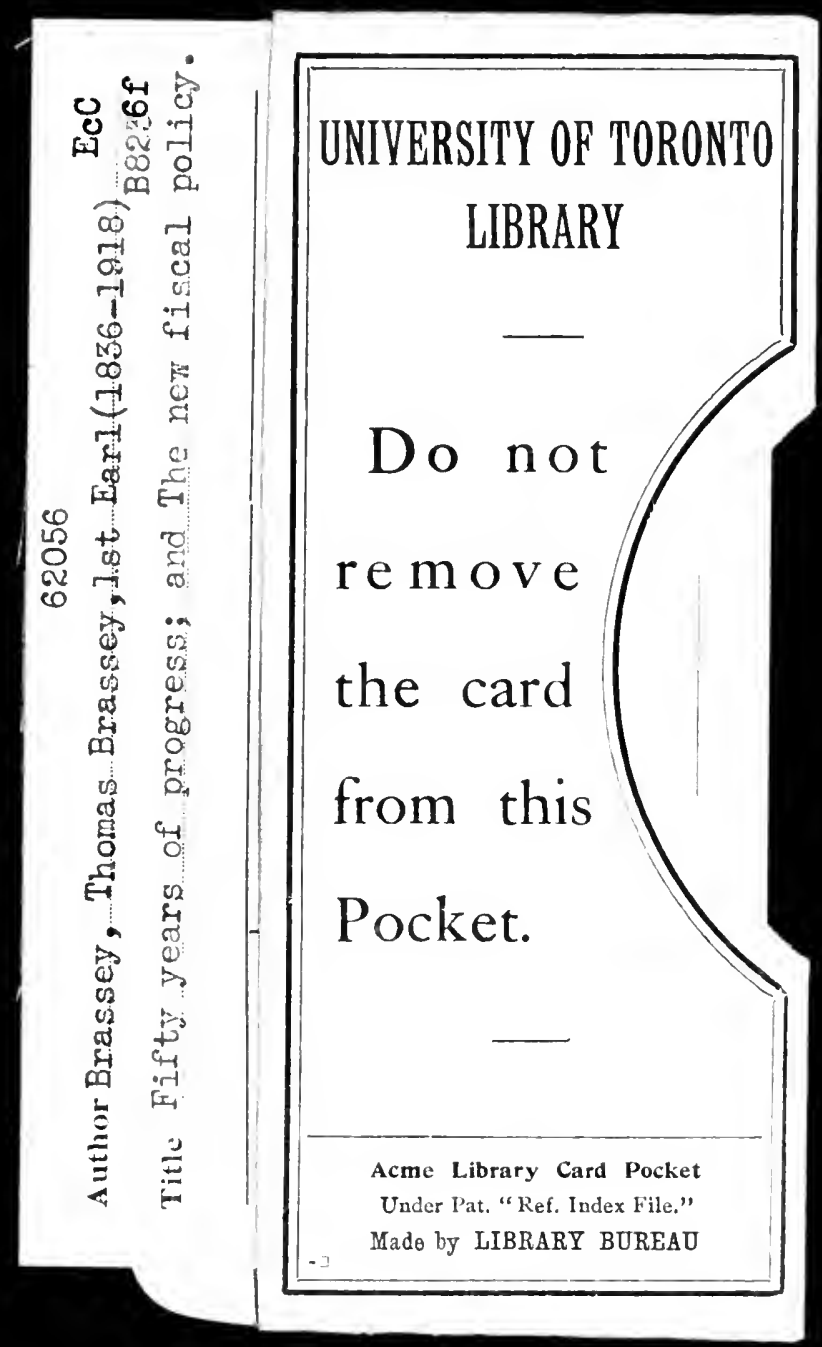


